\title{
Descriptions of Continuous-Type (Unconventional) Plays of the U.S. Geological Survey 1995 National Assessment of United States Oil and Gas Resources
}

\author{
by
}

James W. Schmoker ${ }^{1}$ and Shirley A. Oscarson ${ }^{1}$

Open-File Report 95 -75B

This report is preliminary and has not been reviewed for conformity with U.S. Geological Survey editorial standards and stratigraphic nomenclature.

1USGS Denver 


\section{INTRODUCTION}

The U.S. Geological Survey periodically makes appraisals of the undiscovered oil and gas resources of the Nation. For the 1995 National Assessment (Gautier and others, 1995; U.S. Geological Survey National Oil and Gas Resource Assessment Team, 1995), the onshore areas and adjoining State waters of the Nation have been divided into eight regions which are subdivided into 71 provinces. The basic assessment unit of each province is the play.

This report tabulates and describes those plays of the 1995 National Assessment, other than coalbed gas plays, that represent continuous-type (unconventional) accumulations. A continuous-type gas or oil accumulation is one that is not significantly affected by hydrodynamic or hydrostatic influences, for which the standard methodology of the 1995 National Assessment is not appropriate.

Continuous-type accumulations are essentially large single fields having spatial dimensions equal to or exceeding those of plays. Continuous-type accumulations cannot be represented in terms of discrete, countable entities delineated by down-dip hydrocarbon-water contacts, as are conventional fields, and they cannot be assessed using methods based on the sizes and numbers of discrete fields.

For the 1995 National Assessment, those gas and oil plays identified as continuous-type were assessed using newly developed approaches (Crovelli and Balay, 1995; Schmoker, 1995).

\section{GEOLOGIC NATURE OF CONTINUOUS-TYPE ACCUMULATIONS}

The identification of a continuous-type hydrocarbon accumulation is based on an enduring concept, the geologic setting of the accumulation. This geologically grounded definition does not incorporate ephemeral criteria such as special regulatory status or the concept of unusual engineering techniques, or arbitrary criteria such as a particular low value of API gravity or matrix permeability ("tight"), that are sometimes used to define other types of unconventional accumulations. A legally designated tight-gas accumulation, for example, might or might not be a continuous-type accumulation.

The geologic setting typical of continuous-type accumulations is illustrated by figure 1 . Common geologic characteristics of a continuous-type accumulation include occurrence downdip from water-saturated rocks, lack of obvious trap and seal, crosscutting of lithologic boundaries, large areal extent, relatively low matrix permeability, abnormal pressure (either high or low), and close association with source rocks. Common production characteristics of a continuous-type accumulation include large in-place hydrocarbon volume, low recovery factor, absence of truly "dry" holes, dependence on fracture permeability, and a serendipitous "hit or miss" character for production rates and ultimate recoveries of wells. 


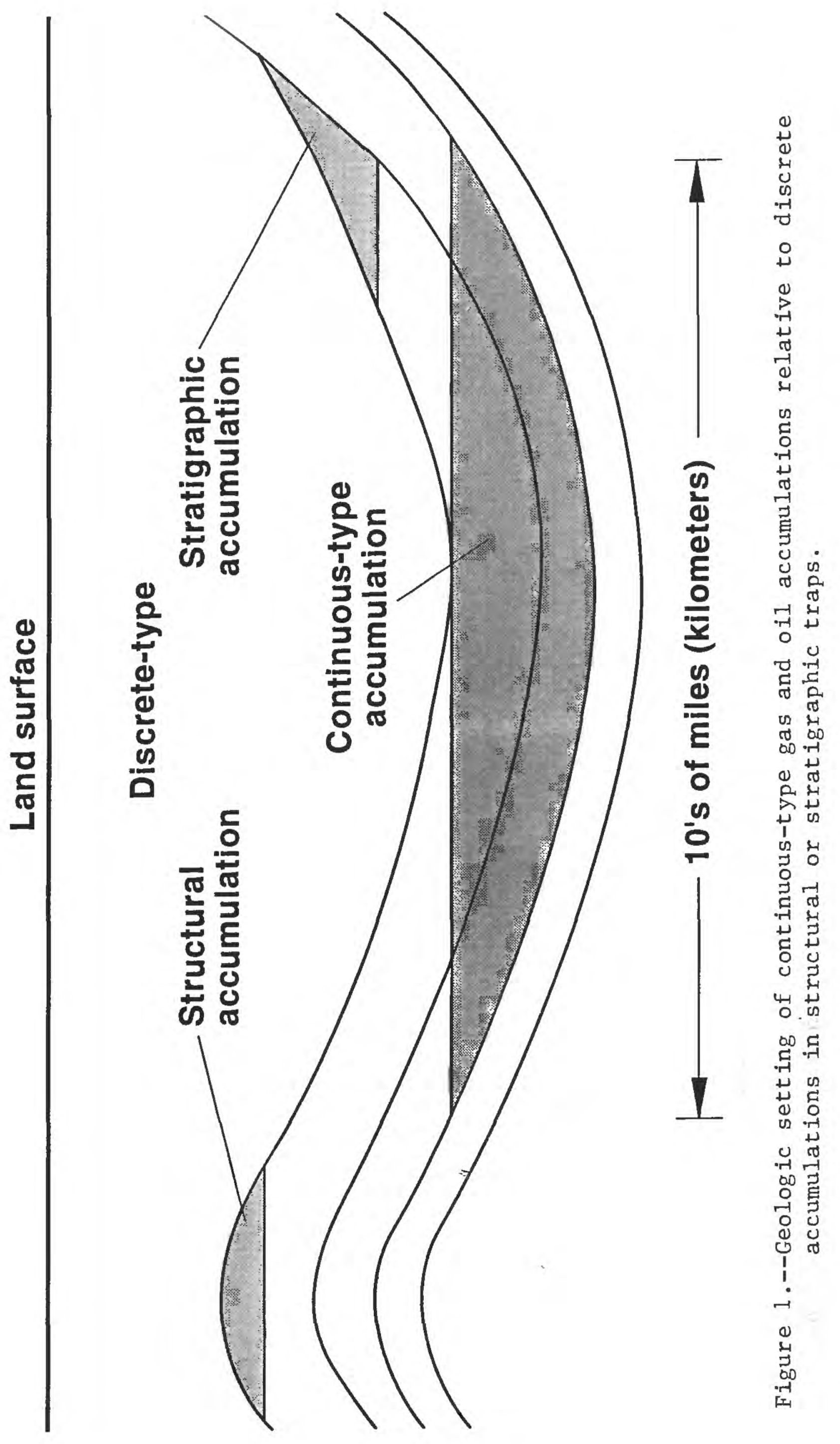


A continuous-type accumulation can be represented by a single play or subdivided into several plays to isolate regions of roughly uniform attributes. For purposes of resource assessment (and perhaps also for exploration and development), it is convenient to envision the hydrocarbons of a continuous-type play as residing in cells. A play can then be regarded as a collection of cells (fig. 2). The cell area is equal to the median spacing, as dictated by drainage area, expected for wells of the play. Virtually all cells in a continuous-type play are capable of producing some hydrocarbons. In the context of the 1995 National Assessment, however, a productive cell is one for which production from the play is formally reported (fig. 2). An untested cell is one that has not been evaluated by a well.

\section{INVENTORY OF UNITED STATES CONTINUOUS-TYPE PLAYS}

Continuous-type plays of the 1995 National Assessment are listed in table 1. Table 2 identifies the assessment regions and provinces referred to by number in table 1 , and figures 3,4 , and 5 are maps showing locations and boundaries of the continuous-type plays.

Identifying those plays that should be treated as continuous-type is difficult at the National scale. Identification of a continuous-type accumulation is based on the general setting and inferred dynamics of the accumulation, but the literature commonly focuses on more narrow geologic properties. From the standpoint of resource assessment, one is often left searching for inadvertently placed clues as to the fundamental nature of the accumulation. The list of plays presented here (table 1) is likely to expand over time, as awareness of continuous-type accumulations increases.

Some continuous-type plays of the 1995 National Assessment were not quantitatively assessed (table 1). In conformity with the protocol adopted for conventional plays, a continuous-type play was not assessed if the play probability was 0.10 or less. In other cases, so little data were available for a play that an effort at quantitative assessment could not be defended.

Sixty-one continuous-type plays were defined for the 1995 National Assessment, of which 47 were assessed (table 1). Of the assessed plays, 34 are gas plays and 13 are oil plays. The predominant reservoir rock is sandstone for 32 plays (fig. 3 ), shale for 20 plays (fig. 4), and carbonate for nine plays (fig. 5). Continuous-type gas and oil accumulations are not geologic oddities limited to one or two United States basins. Twenty-three geologic provinces are represented by the list of continuous-type plays developed for the 1995 National Assessment (table 2). 
Table 1.--List of continuous-type plays (excluding coalbed methane) of the 1995 National Assessment, onshore United States. Regions and provinces are identified in table 2.

\begin{tabular}{|c|c|c|c|c|c|c|}
\hline Reg. & Prov. & Play & Assessed? & $\begin{array}{l}\text { Gas/ } \\
\text { oil }\end{array}$ & Rock Type & Play name \\
\hline 2 & 4 & 412 & no & gas & sandstone & Willamette - Puget Sound Basin-Centered Gas \\
\hline 2 & 5 & 503 & yes & gas & sandstone & Columbia Basin - Basin-Centered Gas \\
\hline 2 & 14 & 1408 & no & gas? & sandstone & $\begin{array}{l}\text { Deep, Overpressured Fractured Rocks of the Central } \\
\text { Syncline }\end{array}$ \\
\hline 3 & 20 & 2007 & yes & gas & sandstone & Tight Gas Piceance Mesaverde Williams Fork \\
\hline 3 & 20 & 2009 & yes & oil & shale & Cretaceous Self-Sourced Fractured Shales \\
\hline 3 & 20 & 2010 & yes & gas & sandstone & Tight Gas Piceance Mesaverde Iles \\
\hline 3 & 20 & 2015 & yes & gas & sandstone & Tight Gas Uinta Tertiary East \\
\hline 3 & 20 & 2016 & yes & gas & sandstone & Tight Gas Uinta Tertiary West \\
\hline 3 & 20 & 2018 & yes & gas & sandstone & Basin Flank Uinta Mesaverde \\
\hline 3 & 20 & 2020 & yes & gas & sandstone & Deep Synclinal Uinta Mesaverde \\
\hline 3 & 21 & 2103 & yes & oil & shale & Fractured Interbed \\
\hline 3 & 22 & 2205 & yes & gas & sandstone & Dakota Central Basin Gas \\
\hline 3 & 22 & 2208 & yes & oil & shale & Mancos Fractured Shale \\
\hline 3 & 22 & 2209 & yes & gas & sandstone & Central Basin Mesaverde Gas \\
\hline 3 & 22 & 2211 & yes & gas & sandstone & Pictured Cliffs Gas \\
\hline 4 & 27 & 2703 & no & oil & carbonate & Cone Calcareous Member, Marias River Shale \\
\hline 4 & 28 & 2804 & yes & oil & shale & Bakken Shale Fracture Systems \\
\hline 4 & 28 & 2810 & yes & gas & sandstone & Northern Great Plains Biogenic Gas, High Potential \\
\hline 4 & 28 & 2811 & yes & gas & sandstone & $\begin{array}{l}\text { Northern Great Plains Biogenic Gas, Moderate } \\
\text { Potential (Suffield Block Analog) }\end{array}$ \\
\hline 4 & 28 & 2812 & yes & gas & sandstone & Northern Great Plains Biogenic Gas, Low Potential \\
\hline
\end{tabular}


Table 1. Continued

Gas/

Reg. Prov. Play Assessed? oil

Rock Type

Play name

$\begin{array}{lllllll}4 & 31 & 3110 & \text { yes } & \text { oil } & \text { shale } & \text { Bakken Fairway } \\ 4 & 31 & 3111 & \text { yes } & \text { oil } & \text { shale } & \text { Bakken Intermediate } \\ 4 & 31 & 3112 & \text { yes } & \text { oil } & \text { shale } & \text { Bakken Outlying } \\ 4 & 31 & 3113 & \text { yes } & \text { gas } & \text { carbonate } & \begin{array}{l}\text { Southern Williston Basin Margin - Niobrara } \\ \text { Shallow Biogenic }\end{array}\end{array}$

$\begin{array}{lllll}43 & 3308 & \text { no } & \text { oil } & \text { shale }\end{array}$

$4 \quad 33 \quad 3311$ no oil shale Niobrara Fractured Shale

$4 \quad 34 \quad 3404$ no gas sandstone Basin-Center Gas

$4 \quad 35 \quad 3505$ no gas sandstone Basin-Center Gas

$4 \quad 37 \quad 3740$ yes gas sandstone Greater Green River Basin - Cloverly-Frontier

$\begin{array}{lllll}3 & 37 & \text { yes } & \text { gas } & \text { sandstone } \quad \text { Greater Green River Basin - Mesaverde }\end{array}$

$4 \quad 37 \quad 3742$ yes gas sandstone Greater Green River Basin - Lewis

$4 \quad 37 \quad 3743$ yes gas sandstone Greater Green River Basin - Fox Hills-Lance

$437 \quad 3744$ yes gas sandstone Greater Green River Basin - Fort Union

$\begin{array}{llllll}4 & 38 & 3803 & \text { no } & \text { oil } & \text { carbonate Upper Cretaceous Niobrara Fractured Shale Oil }\end{array}$

$4 \quad 39 \quad 3904$ yes oil carbonate Greater Wattenberg Codell/Niobrara Oil and Gas

4393906 yes gas sandstone J Sandstone Deep Gas (Wattenberg)

$4 \quad 39 \quad 3911$ no oil shale $\quad$ Fractured Shale - Pierre

$439 \quad 3920$ yes oil carbonate Fractured Niobrara - Greater Silo/Dale Salt-Edge Oil

$4 \quad 39 \quad 3921$ yes oil carbonate Fractured Niobrara - Greater Northern Denver Basin Oil

$545 \quad 4503$ no oil shale Mississippian Barnett Shale 
Table 1. Continued

\begin{tabular}{|c|c|c|c|c|c|c|}
\hline Reg. & Prov. & Play & Assessed? & $\begin{array}{l}\text { Gas/ } \\
\text { oil } \\
\end{array}$ & Rock Type & Play name \\
\hline 6 & 47 & 4747 & yes & oil & carbonate & Austin Chalk-Pearsall \\
\hline 6 & 47 & 4748 & yes & oil & carbonate & Austin Chalk-Giddings \\
\hline 6 & 47 & 4749 & yes & oil & carbonate & Austin Chalk-Outlying \\
\hline 6 & 49 & 4923 & yes & gas & sandstone & Cotton Valley Blanket Sandstones Gas \\
\hline 7 & 58 & 5811 & no & gas & shale & $\begin{array}{l}\text { Woodford/Chattanooga / Arkansas Novaculite of } \\
\text { Midcontinent }\end{array}$ \\
\hline 8 & 63 & 6319 & yes & gas & shale & Antrim Shale Gas, Developed Area \\
\hline 8 & 63 & 6320 & yes & gas & shale & Antrim Shale Gas, Undeveloped Area \\
\hline 8 & 64 & 6407 & yes & gas & shale & Illinois Basin - New Albany Shale Gas \\
\hline 8 & 66 & 6604 & yes & gas & shale & Devonian Black Shale Gas \\
\hline 8 & 67 & 6728 & yes & gas & sandstone & Clinton/Medina Sandstone Gas High Potential \\
\hline 8 & 67 & 6729 & yes & gas & sandstone & Clinton/Medina Sandstone Gas Medium Potential \\
\hline 8 & 67 & 6730 & yes & gas & sandstone & $\begin{array}{l}\text { Clinton/Medina Sandstone Gas Medium-Low } \\
\text { Potential }\end{array}$ \\
\hline 8 & 67 & 6731 & no & gas & sandstone & Clinton/Medina Sandstone Gas Low Potential \\
\hline 8 & 67 & 6733 & yes & gas & sandstone & Upper Devonian Sandstone Gas High Potential \\
\hline 8 & 67 & 6734 & yes & gas & sandstone & Upper Devonian Sandstone Gas Medium Potential \\
\hline 8 & 67 & 6735 & yes & gas & sandstone & $\begin{array}{l}\text { Upper Devonian Sandstone Gas Medium-Low } \\
\text { Potential }\end{array}$ \\
\hline 8 & 67 & 6736 & no & gas & sandstone & Upper Devonian Sandstone Gas Low Potential \\
\hline 8 & 67 & 6740 & yes & gas & shale & Devonian Black Shale - Greater Big Sandy \\
\hline 8 & 67 & 6741 & yes & gas & shale & Devonian Black Shale - Greater Siltstone Content \\
\hline 8 & 67 & 6742 & yes & gas & shale & Devonian Black Shale - Lower Thermal Maturity \\
\hline 8 & 67 & 6743 & no & gas & shale & $\begin{array}{l}\text { Devonian Black Shale - Undeveloped NE Ohio } \\
\text { and Western Pennsylvania }\end{array}$ \\
\hline
\end{tabular}


Table 2.-List of assessment regions and provinces referred to by number in table 1 .

\begin{tabular}{|c|c|c|}
\hline Region & Province & Region or province name \\
\hline \multirow[t]{4}{*}{2} & & cific Coast \\
\hline & 4 & Western Oregon-Washington \\
\hline & 5 & Eastern Oregon-Washington \\
\hline & 14 & Los Angeles Basin \\
\hline \multirow[t]{4}{*}{3} & & lorado Plateau and Basin and Range \\
\hline & 20 & Uinta-Piceance Basin \\
\hline & 21 & Paradox Basin \\
\hline & 22 & San Juan Basin \\
\hline \multirow[t]{10}{*}{4} & & cky Mountains and Northern Great Plains \\
\hline & 27 & Montana Thrust Belt \\
\hline & 28 & North-Central Montana \\
\hline & 31 & Williston Basin \\
\hline & 33 & Powder River Basin \\
\hline & 34 & Big Horn Basin \\
\hline & 35 & Wind River Basin \\
\hline & 37 & Southwestern Wyoming \\
\hline & 38 & Park Basins \\
\hline & 39 & Denver Basin \\
\hline \multirow[t]{2}{*}{5} & & est Texas and Eastern New Mexico \\
\hline & 45 & Bend Arch-Fort Worth Basin \\
\hline \multirow[t]{3}{*}{6} & & lf Coast \\
\hline & 47 & Western Gulf \\
\hline & 49 & $\begin{array}{l}\text { Louisiana-Mississippi Salt Basins (includes Province } \\
\text { 48-East Texas Basin) }\end{array}$ \\
\hline \multirow[t]{2}{*}{7} & & id-Continent \\
\hline & 58 & Anadarko Basin \\
\hline \multirow[t]{5}{*}{8} & & stern \\
\hline & 63 & Michigan Basin \\
\hline & 64 & Illinois Basin \\
\hline & 66 & Cincinnati Arch \\
\hline & 67 & Appalachian Basin \\
\hline
\end{tabular}




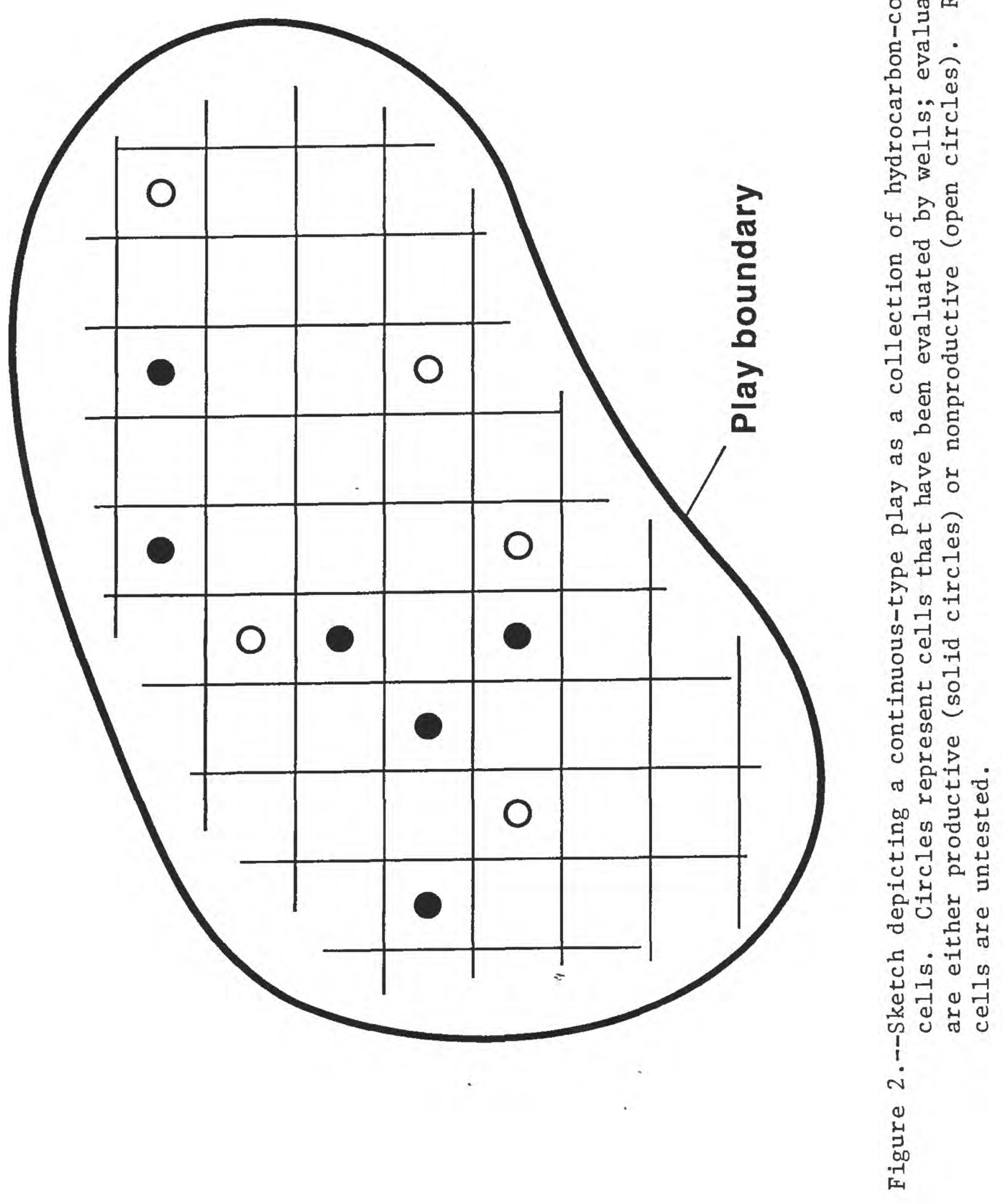




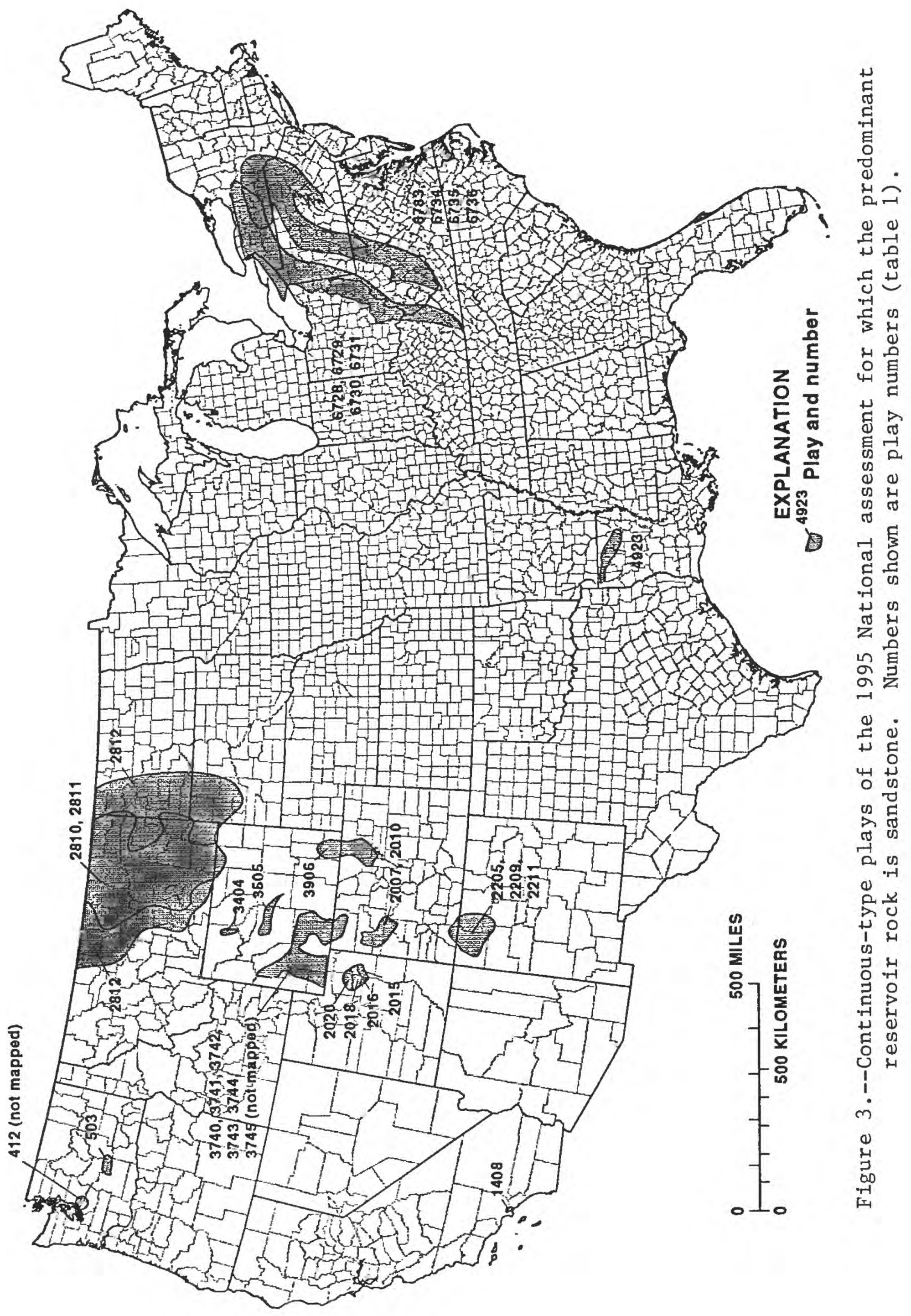




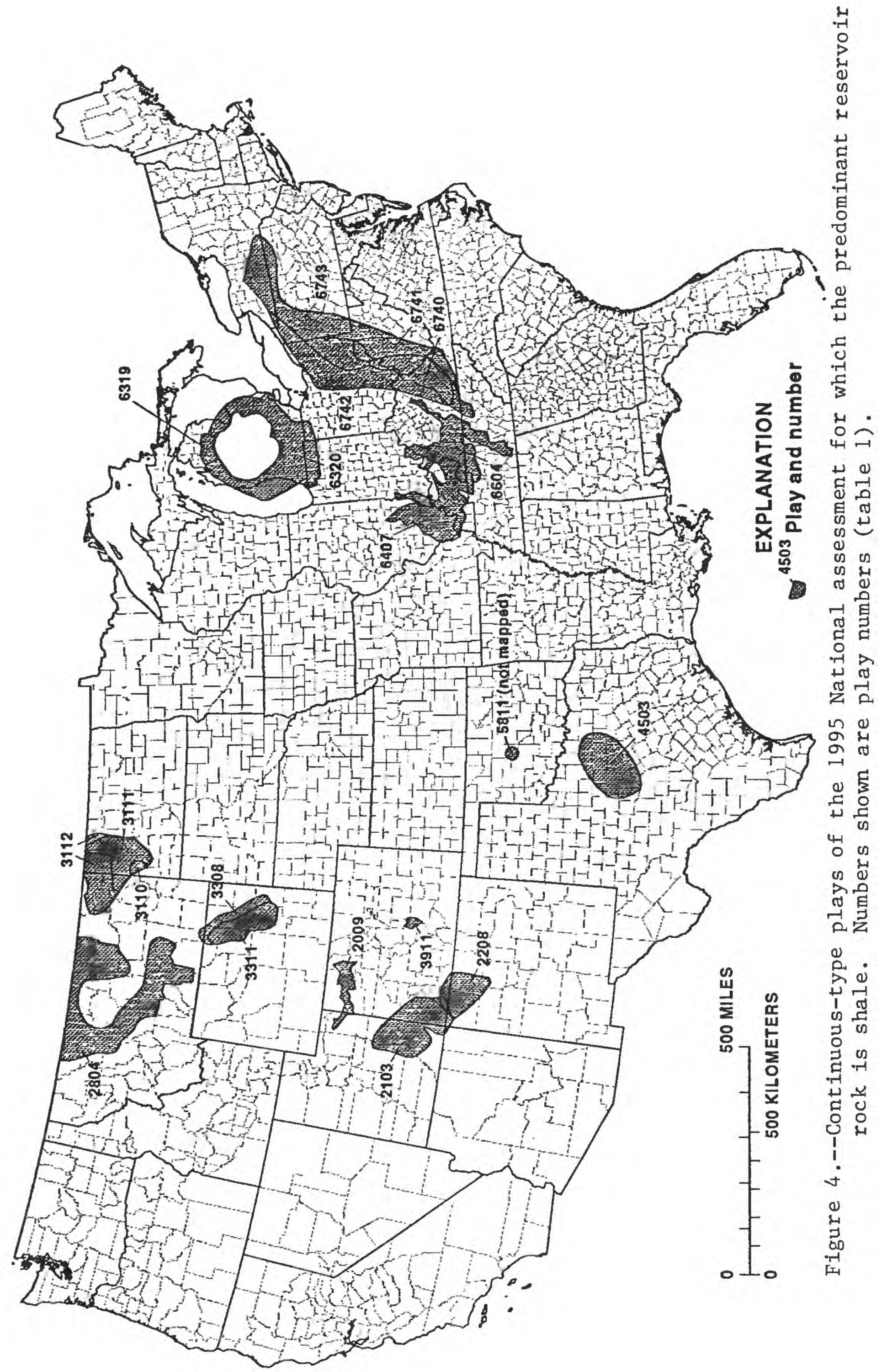




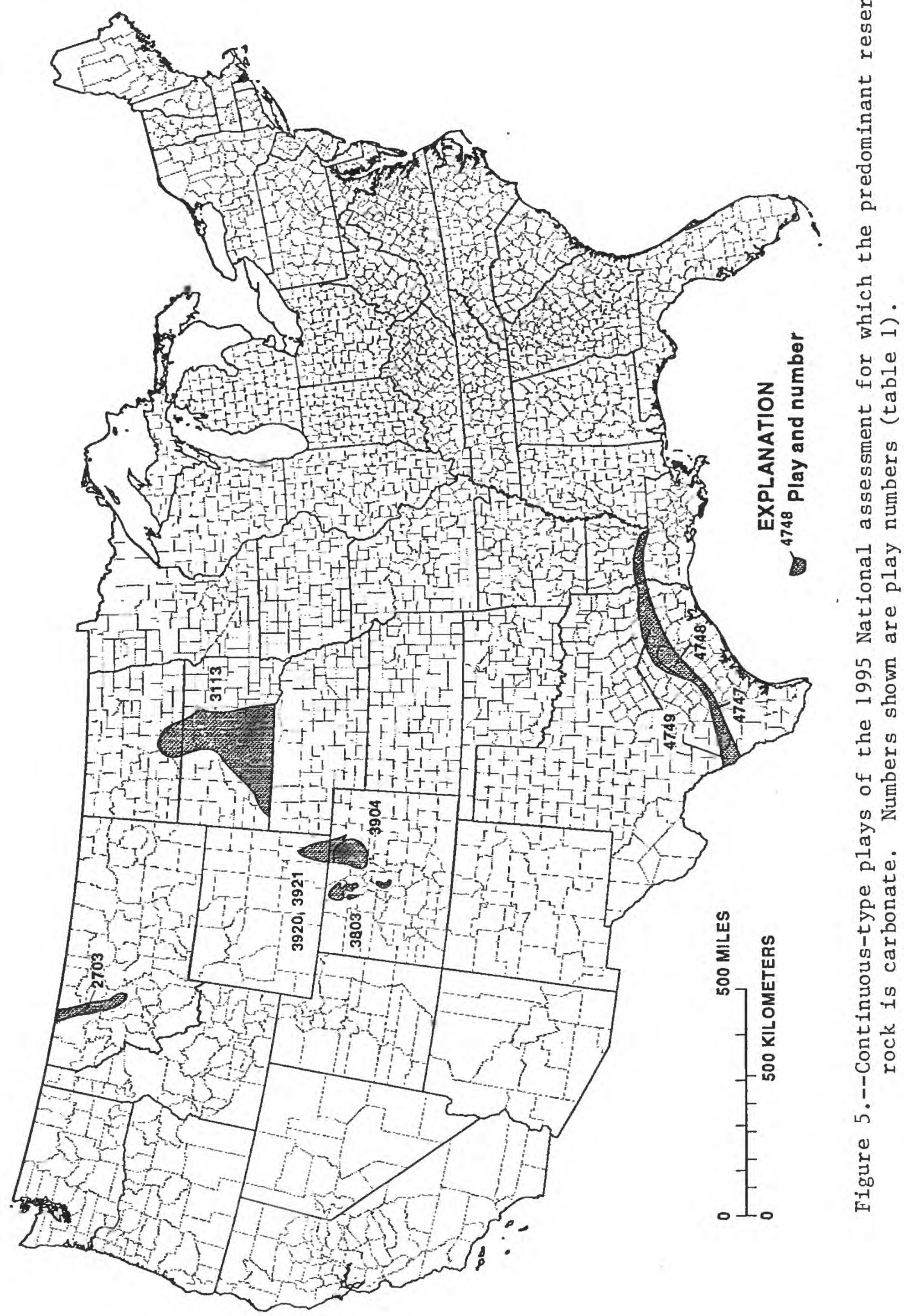




\section{DESCRIPTIONS OF CONTINUOUS-TYPE PLAYS}

In this section, each continuous-type play listed in table 1 is described in narrative form. The play narratives, arranged in order of increasing play number, are abridged from those presented in the comprehensive documentation of the 1995 National Assessment (Gautier and others, 1995). The original author of each narrative is identified following the play number and name.

\section{REGION 2--PACIFIC COAST}

\section{2.--Willamette - Puget Sound Basin-Centered Gas (modified from original narrative written by Ben E. Law)}

The Willamette-Puget Sound Trough, located immediately west of the Cascade Mountains in Oregon and Washington, contains several smaller basins that include the Tualatin and Nehalem Basins in Oregon and the Chehalis, Tacoma, Seattle, and Everett Basins in Washington. These forearc basins are filled with Eocene and younger sedimentary rocks that were deposited in fluvial systems and may be as thick as 30,000 $\mathrm{ft}$.

Only a few wells have been drilled in this play area that are deep enough to determine the presence of a basin-centered gas accumulation. Subsurface data from two wells, the Exxon GPE Federal Com. No. 1 well, located in the Nehalem Basin of northwestern Oregon and the Phillips State No. 1 well, located in the Tacoma Basin of west-central Washington, were drilled to depths of $11,287 \mathrm{ft}$ and $12,920 \mathrm{ft}$, respectively. The top of abnormally high reservoir pressure occurs in these wells at depths of 8,000 to 9,600 feet, and the level of vitrinite reflectance at these depths is about 0.8 percent. These relationships, in conjunction with the presence of interbedded coal and probable lowpermeability reservoirs, indicate the presence of a basin-centered gas accumulation. However, because some deeply drilled wells in the area do not indicate the presence of a basin-centered gas accumulation and because of uncertainties regarding the geometry of the basins in the Willamette-Puget Sound Trough, the spatial and areal distribution of these basin-centered gas accumulations cannot be determined.

Sandstone reservoirs in this play are in Eocene and possibly older rocks. Borehole data indicate that gas-bearing reservoirs occur in an interval that is at least 3,300 ft thick. The bottom of the basin-centered gas accumulation is not known because the entire gasbearing interval has not been penetrated. No porosity or permeability data are available from the reservoirs in the overpressured interval. Qualitative estimates of porosity and permeability are low.

In the absence of source rock analyses, the most likely sources of gas are the interbedded coals and carbonaceous shales. The levels of thermal maturity at the top of the gas accumulation are sufficiently high to generate gas from available organic matter. Published and unpublished source rock analyses from various rock units in the Pacific Northwest indicate that nearly all of the organic matter is type III kerogen. 
Present-day temperatures at depths of $8,000-9,600 \mathrm{ft}$ are about $130-150^{\circ} \mathrm{F}$, too low to have achieved the present level of thermal maturity at that depth. Therefore, this area has experienced higher temperatures in the past than present-day temperatures.

The Willamette - Puget Sound Basin-Centered Gas Play is immaturely explored. Previous exploration activity in the play area has focused on more traditional structural and stratigraphic plays. This region has not been evaluated in the context of basincentered gas accumulations.

\section{3.--Columbia Basin - Basin-Centered Gas (modified from original narrative written by Ben E. Law)}

This play underlies the widespread Miocene Columbia River Basalt in eastern Washington. The thickness of the basalt is highly variable. The few wells that have drilled through the basalt show that it is commonly in excess of 5,000 ft thick. Through most of the play area, the subvolcanic rocks consist of lower Tertiary fluvial and lacustrine rocks of highly variable thicknesses. Interpretations of subsurface data from six widely spaced wells indicate the presence of a basin-centered gas accumulation. The well data show that the top of a thick, overpressured interval begins at depths ranging from 8,300 to $12,700 \mathrm{ft}$. Within the overpressured interval, large amounts of gas have been recovered on drill-stem tests. Although some water has also been recovered, most of the zones produced gas with no water. The areal and spatial extents of the accumulation are imprecisely known because of insufficient deep drilling and uncertainties about the geometry of pre-volcanic basins.

Reservoirs consist of Eocene arkosic fluvial sandstones. The quality of these reservoirs is unknown, although they are thought to contain volcanic material that has resulted in very low permeability. Porosity values ranging from 6 to 15 percent have been calculated from well logs. The thickness of the gas-bearing interval is at least $6,400 \mathrm{ft}$. The maximum thickness is unknown because the gas-bearing interval has not been entirely penetrated.

The sources of gas are assumed to be interbedded coals and carbonaceous rocks. Regional source rock studies in Washington and Oregon indicate that nearly all organic matter in the region is type III kerogen. The level of thermal maturity within the gasbearing interval is sufficiently high ( 0.6 percent vitrinite reflectance) to generate gas. Present-day temperatures appear to be in or near equilibrium with measured levels of thermal maturity.

The play is immaturely explored. Five wells penetrate the gas accumulation and several production tests have been made. These tests flowed gas at initial rates as high as 3.1 million cubic feet per day. Previous exploration activity in the play area has focused on more conventional structural and stratigraphic plays. The region has not been evaluated in the context of basin-centered gas accumulations. 


\section{8.--Deep, Overpressured Fractured Rocks of the Central Syncline (modified from original narrative written by Larry $A$. Beyer)}

This play is based largely on the American Petrofina Central Core Hole well (sec. 4, T. 3 S., R. 13 W.) which encountered overpressured rocks, tested moderately high gravity oil, and bottomed in lowermost Delmontian rocks at $21,215 \mathrm{ft}$ in the central syncline. The conceptual reservoir is fractured rock. The Mohnian section has not been reached by drill in the central syncline. Based on inferred depth to basement in the central syncline and projected thicknesses of upper Miocene rocks northeast and southwest of the central syncline, the lower Mohnian section probably is less than 3,000 to $7,000 \mathrm{ft}$ thick in the syncline.

Stresses responsible for postulated fracturing of reservoir rocks might be caused by fluid overpressuring during maturation of kerogen in the organic-rich shales. Late Miocene and early Pliocene extensional faulting and more recent north-south compression of the southwest flank of the central syncline might also have contributed to fracturing. The compressional tectonics since the Pliocene might have locally enhanced fracturing along the deep syncline-bounding faults. This faulting also could have provided expulsion routes except where diagenetic alteration kept seals intact. The presence of overpressuring in the American Petrofina Central Core Hole well suggests some seals remain intact.

Source rocks may be the less terrigenous parts of the lower Mohnian section, possibly analogous to the organic-rich basal unit ("nodular shale") on the southwestern shelf. Vitrinite reflectance values increase rapidly toward the bottom of the American Petrofina Central Core Hole well, where values greater than 1.2 percent were observed. Maturation of hydrocarbons probably began during early Pliocene time or earlier and continues today. Laumontite is reported at depth in the American Petrofina well and may degrade the quality of reservoir rocks or even help form reservoir seals.

The play is unexplored except for the American Petrofina Central Core Hole well, which confirmed the presence of hydrocarbons but does not confirm that reservoir rocks are present. The American Petrofina Central Core Hole tested oil of $43^{\circ}$ API gravity with moderate to high gas-oil ratio near total depth. Other, shallower wells on the east flank of the Newport-Inglewood zone of deformation penetrated important amounts of interbedded sandstone and shale with type II kerogen in the lower Mohnian section. Condensate or gas also are likely at the depths of this play.

Because of the known organic richness of Luisian and lower Mohnian source rocks along the northeast and southwest margins of the central syncline, one can infer that large amounts of hydrocarbons have been generated in the central syncline where these organic-rich rocks are presumed to be present. The possibility that some of this generated petroleum remains trapped at great depth in suitable reservoir rocks is very problematical and a quantitative analysis is not possible. 


\section{REGION 3--COLORADO PLATEAU AND BASIN AND RANGE}

\section{7.--Tight Gas Piceance Mesaverde Williams Fork (modified from original narrative written by Charles W. Spencer)}

This play consists of gas trapped in low-permeability sandstones in a typical continuous-type basin-center gas accumulation containing gas downdip and water updip. Boundaries of this play are based on mapping the thermal maturity of sandstone reservoirs in the Upper Cretaceous Williams Fork Member of the Mesaverde Group.

The reservoirs in the Williams Fork Member are medium- to fine-grained litharenites that were deposited in fluvial environments. They vary in thickness from less than $10 \mathrm{ft}$ to more than $50 \mathrm{ft}$. They are interbedded with organic-rich mudstones, siltstones, and shales, and some coals in the lower part. Porosity ranges from less than 5 percent to more than 8 percent. The thickness of the Williams Fork Member ranges from about $1,500 \mathrm{ft}$ to $4,500 \mathrm{ft}$. Drill depths for tight beds in the Williams Fork vary from $5,500 \mathrm{ft}$ to more than $9,800 \mathrm{ft}$, with an average of $7,500 \mathrm{ft}$.

The source rocks are interbedded gas-prone shales, mudstones, siltstones, and coals. The play outline encompasses all the Williams Fork Member that has attained a vitrinite reflectance in oil $\left(R_{0}\right)$ of 0.73 percent or higher.

The play is only moderately well explored. Several "sweet spots" have been developed (for example, Rulison). The play has major potential for additional recoverable gas resources, especially if prices increase and technology improves. Innovative techniques such as artificial fracturing with gas or slant- and horizontal-hole drilling will likely be used in the future. A few horizontal Mesaverde wells have been drilled, and anomalous amounts of water have been tested, whereas vertical wells in the same areas do not produce significant amounts of water. The water might be coming from water at the bottom of open natural fractures, which were not flushed by gas charging from adjacent source beds. This condition might be somewhat analogous to water found in coalbed cleats.

\section{9.--Cretaceous Self-Sourced Fractured Shales(modified from original narrative written by Charles W. Spencer)}

Oil is produced from fractured Upper Cretaceous Mancos Shale and its equivalents. The best fracturing occurs in brittle siltstones, carbonates, and calcareous shale. This play crosses the province boundary into the Southwestern Wyoming Province (37). The play outline is based on the known occurrence of production and the tectonic features associated with known and suspected production potential. The best open fractures occur at the maximum flexure on anticlines or monoclines. Fractures also produce where shear zones or faults occur.

Reservoirs are open fractures in brittle siltstones, carbonates, and calcareous shale and siliceous shale. The producing interval can be $10 \mathrm{ft}$ to more than $50 \mathrm{ft}$ thick. Fracturing 
is highly variable. One well in the play has produced over 1 million barrels of oil. The source rocks are the enclosing marine shale. The organic richness varies from about 1 percent to more than 4 percent total organic carbon, based on unpublished information.

The play is moderately well explored by vertical wells but nearly unexplored by slantand horizontal-hole drilling. A low success ratio is assumed for the overall play area. Although this play is classified as a continuous-type play, production will be localized by individual fractured structures and fracture trends. The success ratio in structural flexures will be quite high, perhaps more than 50 percent, and high potential exists for finding small areas of production.

\section{0.--Tight Gas Piceance Mesaverde Iles (modified from original narrative written by Charles W. Spencer)}

Although this play directly underlies the Tight Gas Piceance Williams Fork Play (2007), which occurs in fluvial deposits, the Iles reservoirs are predominantly marine and marginal marine, and some intertongue with the Upper Cretaceous Mancos Shale. The play boundary is based on that part of the Upper Cretaceous Iles Member that has attained a vitrinite reflectance of 0.73 percent or higher. The accumulation is a typical basin-center gas accumulation charged with gas throughout and having water updip.

The Iles Member reservoirs are medium- to fine-grained litharenites that were deposited in a regressive marginal marine environment. The Iles is about $500-1,500 \mathrm{ft}$ thick. Drill depths for tight beds in the lles vary from about $5,800 \mathrm{ft}$ to more than 10,000 $\mathrm{ft}$, averaging $7,700 \mathrm{ft}$. The source rocks are interbedded gas-prone shales, mudstones, and siltstones.

The play is only moderately explored by drilling. Several "sweet spots" have been developed. Increased gas prices and improved recovery technology will eventually cause local fields to merge into one basin-wide gas field.

\section{5.--Tight Gas Uinta Tertiary East (modified from original narrative written by Thomas $D$. Fouch and James W. Schmoker)}

This play is based on well-established gas production in the Uteland Butte, Chapita, and Buck Canyon zones of the Tertiary Wasatch Formation. Updip to the south and east, the play limit is based on a change to mostly conventional reservoirs that have gaswater contacts.

Downdip to the north, the play limit is based on a transition from gas to oil. The west limit is along the Green River drainage, where the play becomes higher risk and is assessed separately as Tight Gas Uinta Tertiary West Play (2016). The Wasatch tight gas plays (2015 and 2016) overlie vitrinite-reflectance levels of 1.1 percent or higher in the basal Cretaceous Mesaverde. Gas in the Wasatch has migrated upward from the Mesaverde.

Reservoir rocks are generally medium- to fine-grained feldspathic litharenites mostly deposited in fluvial environments. They are interbedded with mudstone, siltstone, 
shale, and some coal. Porosity ranges from less than 5 percent to more than 9 percent. The reservoirs range in depth from about $3,000 \mathrm{ft}$ to about $10,500 \mathrm{ft}$, having a median depth of $6,400 \mathrm{ft}$.

The play is moderately well explored, and several "sweet spots" have been found. Most of the play area will eventually be productive.

2016.--Tight Gas Uinta Tertiary West (modified from original narrative written by Thomas D. Fouch and James W. Schmoker)

This play is the western extension of Tight Gas Uinta Tertiary East Play (2015) and is separated from Play 2015 by the Green River. Although the river is a surface feature, it coincides with a decrease in drilling activity and reservoir quality westward.

This play has the same reservoir rocks as Play 2015 but here they apparently have lower porosity, ranging from less than 4 percent to about 8 percent in reservoir sandstones. Play depths range from about $4,500 \mathrm{ft}$ to $11,000 \mathrm{ft}$, having a median depth of $7,500 \mathrm{ft}$. The underlying Mesaverde is the gas source. Vertical gas migration from the Mesaverde may not have been as effective as in Play 2015.

Considerably less drilling activity has occurred in this play relative to Play 2015. The play is only sparsely explored by drilling.

\section{8.--Basin Flank Uinta Mesaverde (modified from original narrative written by Thomas D. Fouch and James W. Schmoker)}

This play is based on the widespread occurrence of tight, gas-charged continental and marginal marine sandstone. The south, east, and west limits of the play are based on thermal-maturation levels in the basal part of the Upper Cretaceous Mesaverde Group. The reservoirs grade updip into conventional Mesaverde reservoirs having gas-water contacts. The downdip (north) play boundary is placed at a Mesaverde burial depth of $15,000 \mathrm{ft}$.

The reservoirs are fine- to medium-grained litharenites to feldspathic litharenites, becoming coarser to the west. Permeabilities of most reservoirs are less than 0.1 millidarcy. Porosity ranges from less than 4 percent to more than 12 percent, averaging about 8 percent. Play depth varies from $8,000 \mathrm{ft}$ to $15,000 \mathrm{ft}$, having a median of $9,500 \mathrm{ft}$. Source rocks are gas-prone thermally mature coals, carbonaceous shales, and mudstones in the Mesaverde Group. The basal Mesaverde within the play has a vitrinite reflectance higher than 1.1 percent.

The play is essentially unexplored because of depth, economics, poor reservoir quality, and the fact that it is mostly overlain by oil- and gas-producing rocks of the Tertiary Wasatch and Green River Formations, which are the primary exploration targets in the area. 


\section{0.--Deep Synclinal Uinta Mesaverde (modified from original narrative written by Thomas D. Fouch and James W. Schmoker)}

This play is based on the expected occurrence of gas-charged tight Upper Cretaceous Mesaverde sandstone at depths greater than 15,000 ft. The play borders Play 2018 and involves the same types of rocks.

Reservoir rocks are sandstones interbedded with mudstones, siltstones, shales, and some coals. Porosity is generally poorer than in Play 2018. Median porosity is expected to be 5-6 percent. Reservoir depths are more than $15,000 \mathrm{ft}$ and as much as $25,000 \mathrm{ft}$, having a median of $20,000 \mathrm{ft}$. Gas-prone organic material interbedded with the sandstone reservoirs has generated large volumes of gas. The vitrinite reflectance of the Mesaverde within the play is in excess of 1.5 percent.

Very few wells penetrate the play. The primary interest in the area has been the overlying Tertiary reservoirs.

\section{3.--Fractured Interbed (modified from original narrative written by A.C. Huffman, Jr.)}

This play in the Pennsylvanian Paradox Formation is oil prone throughout most of the Paradox Basin but becomes gas prone to the east near the ancestral Uncompahgre uplift because of increased depth of burial and greater percentage of terrestrial organic matter. The play depends on extensive fracturing in the organic-rich dolomitic shale and mudstone in the interbeds between evaporites of the Paradox Formation or carbonate and clastic rocks of the related cycles on the shelf of the Paradox evaporite basin. These shales and mudstones may be as thick as $130 \mathrm{ft}$ but are more commonly less than $20 \mathrm{ft}$ thick. Depths to potential targets vary from more than $15,000 \mathrm{ft}$ near the eastern basin margin to less than $5,000 \mathrm{ft}$ on the Four Corners platform.

The organic-rich black dolomitic shales and mudstones of the Paradox Formation are the source rocks for most, if not all, of the oil and gas in the Paradox Basin. Total organic carbon commonly ranges from 1 to 5 percent but may be as high as 20 percent. The thermal history of these rich source rocks is determined mostly by depth of burial and to a lesser degree by the added affect of Oligocene volcanic activity.

Pennsylvanian, Permian, Late Cretaceous, and early Tertiary sediments thicken significantly to the east so that the Pennsylvanian section entered the thermal zone of oil and gas generation at different times depending on location. Close to the Uncompahgre uplift, Pennsylvanian rocks might have generated oil as early as the Permian; elsewhere these rocks might have entered the oil generation window in the Late Cretaceous and the dry gas window as late as the Oligocene.

Until recently, the only significant production from this play was from the Cane Creek Shale in the Lone Canyon field discovered in 1962. Recently, nearby Bartlett Flat field has been developed by directional drilling in the Cane Creek Shale at a depth of approximately 9,000 ft. The Cane Creek, Chimney Rock, Gothic, and Hovenweep Shales have the most potential due to greater organic content and thickness. 
2205.--Dakota Central Basin Gas (modified from original narrative written by A.C. Huffman, Jr.)

This play is based on coastal marine barrier-bar sandstone and continental fluvial sandstone units within the transgressive Lower Cretaceous Dakota Sandstone. Reservoir quality is highly variable. Porosities range from 5 to 15 percent and permeabilities from 0.1 to 0.25 millidarcy. Fracturing, both natural and induced, is essential for effective field development. The primary source rock is probably the marine Upper Cretaceous Mancos Shale.

In the northern part of the central San Juan Basin, the Dakota Sandstone and Mancos Shale entered the oil generation window in the Eocene and were elevated to temperatures appropriate for the generation of dry gas by the late Oligocene. Along the southern margin of the central basin, the Dakota and lower Mancos entered the thermal zone of oil generation during the late Miocene. The Dakota gas accumulation is on the flanks and bottom of a large depression and is not localized by structural trapping. Production is primarily at depths ranging from 6,500 to $7,500 \mathrm{ft}$.

The Dakota discovery well in the central basin was drilled in 1947 southeast of Farmington, New Mexico, and the Basin field, containing the Dakota gas pool, was formed February 1, 1961 by combining several existing fields. By the end of 1993 it had produced over 4.0 trillion cubic feet of gas. Almost all of the Dakota interval in the central part of the basin is charged with gas, and additional gas discoveries within the Basin field and around its margins are probable.

2208.--Mancos Fractured Shale (modified from original narrative written by A.C. Huffman, Jr.)

This play is dependent on extensive fracturing in the organic-rich marine Upper Cretaceous Mancos Shale. Most developed fields in the play are associated with anticlinal and monoclinal structures around the eastern, northern, and western margins of the San Juan Basin. Reservoirs are fractured shale and interbedded coarser clastic intervals at approximately the Tocito Lentil stratigraphic level.

The Mancos Shale contains 1-3 weight percent organic carbon and produces a sweet, low-sulfur, paraffin-base oil. The Mancos Shale of the central part of the San Juan Basin entered the thermal window of oil generation in the late Eocene and of gas generation in the Oligocene.

Most of the larger discoveries such as Verde and Puerto Chiquito fields were made prior to 1970, but directional drilling along the flanks of poorly explored structures could result in renewed interest in this play.

2209.--Central Basin Mesaverde Gas (modified from original narrative written by A.C. Huffman, Jr.)

This play is in sandstone buildups in the Upper Cretaceous Point Lookout and Cliff House Sandstones of the Mesaverde Group. Smaller amounts of dry, nonassociated gas 
are produced from thin, lenticular channel sandstone reservoirs and thin coal beds of the intervening nonmarine Menefee Formation. Total thickness of the interval ranges from about 500 to $2,500 \mathrm{ft}$, of which 20-50 percent is sandstone. The Mesaverde is enclosed by the marine Mancos Shale below and the marine Lewis Shale above. Reservoir quality depends mostly on the degree of fracturing. Production depths are commonly from 4,000 to $5,300 \mathrm{ft}$. Geochemical data suggest a mixture of source rocks including coal and carbonaceous shale in the Menefee Formation.

In the central part of the basin, the Mancos Shale entered the thermal window of oil generation in the Eocene and of gas generation in the Oligocene. The Menefee Formation also entered the gas generation window in the Oligocene. Because basin configuration was similar to that of today, updip migration would have been toward the south.

The Blanco Mesaverde field discovery well was completed in 1927, and the Ignacio Blanco Mesaverde field discovery well was completed in 1952. Areally, these adjacent fields cover more than 1,000,000 acres, encompass much of the central part of the San Juan Basin, and have produced almost 7.0 trillion cubic feet of gas.

\section{1.--Pictured Cliffs Gas (modified from original narrative written by A.C. Huffman, Jr.)}

This play is defined primarily by gas production from sandstone reservoirs enclosed in shale or coal at the top of the Upper Cretaceous Pictured Cliffs Sandstone and is confined to the central part of the basin. Thicker shoreline sandstones have been the most productive. The Pictured Cliffs is the uppermost regressive marine sandstone in the San Juan Basin. It ranges in thickness from 0 to $400 \mathrm{ft}$ and is conformable with both the underlying marine Lewis Shale and the overlying nonmarine Fruitland Formation.

Reservoir quality is controlled to a large extent by the abundance of authigenic clay. Average porosity is about 15 percent and permeability averages 5.5 millidarcies, although many reservoirs have permeabilities less than 1 millidarcy. Pay thicknesses range from 5 to $150 \mathrm{ft}$ but typically are less than $40 \mathrm{ft}$. Reservoir quality improves southward from the deepest parts of the basin due to secondary diagenetic effects. The source of gas was probably marine shale of the underlying Lewis Shale and nonmarine shale of the Fruitland Formation. The Pictured Cliffs crops out around the perimeter of the San Juan Basin and is present at depths of as much as $4,300 \mathrm{ft}$. Most production has been from depths of 1,000-3,000 ft.

Gas was discovered in the play in 1927 at the Blanco and Fulcher Kutz fields of northwest New Mexico. Most Pictured Cliffs fields were discovered before 1954, and only nine relatively small areas have come into production since then. A large quantity of gas is held in tight sandstone reservoirs north of the currently producing areas. Excellent source rocks are present in the deeper parts of the basin, but low permeabilities have thus far limited production. 


\title{
REGION 4--ROCKY MOUNTAINS AND NORTHERN GREAT PLAINS
}

\author{
2703.--Cone Calcareous Member, Marias River Shale (modified from original narrative \\ written by William J. Perry, Jr.)
}

The calcareous Cone Member of the Cretaceous Marias River Shale in the Montana Disturbed Belt is a good potential source rock for oil because of relatively high hydrogen index values and above average organic carbon values. The entire Marias River Shale is from 1,200 to 1,300 ft thick in the Disturbed Belt. Oil-stained fractures are common in the Cone Member where it is exposed in the Disturbed Belt. Marine shales assigned to the Marias River extend southeastward into the Lewis and Clark Fault Zone in the footwall of the Eldorado Thrust System. Anticipated depths to the Cone Member range from less than $2,500 \mathrm{ft}$ at the eastern edge of the play to more than $13,000 \mathrm{ft}$ beneath the front of the Lewis Thrust.

The play area comprises $3408 \mathrm{sq} \mathrm{mi}$ in the northeastern part of the Montana Thrust Belt. The eastern and western limits are the vitrinite reflectance contours of 0.6 and 1.5 percent, respectively. The Cone Member is considered to represent a continuous-type oil deposit based on oil production from a relatively low structural position lateral to anticlinal and thrust-imbricate closures in the top of the Madison in the East Glacier field. The oil has not been expelled from its source, and conventional oil-water contacts are not documented.

About 70 wildcat wells have drilled through the Cone Member within the play area. Many have reported good oil shows. Production (cumulative through 1992) from the two-well East Glacier field is 22,620 barrels of oil. The first oil well in Montana, completed in 1905 in the eastern part of what is now Glacier National Park, probably produced from fractured Cone. An excellent chance exists for oil production from fractured Cone within the play area, particularly if wells are drilled to encounter the maximum number of fractures.

\section{4.--Bakken Shale Fracture Systems (modified from original narrative written by Thaddeus S. Dyman)}

This play is defined as an analog to known Devonian-Mississippian Bakken production in the Williston Basin, but no production has been identified in the Bakken Formation within the North-Central Montana Province. The Bakken is more than $100 \mathrm{ft}$ thick in the northeastern part of the province and in the Williston Basin, but is thin or absent on the Sweetgrass Arch and south.

Bakken shale is the likely source for Mississippian Sun River (Madison) reservoirs along the Sweetgrass Arch. The Bakken is thermally mature in the Disturbed Belt to the west and northwest, and oil may have migrated updip into traps along the arch. However, thermal maturities decrease rapidly away from the thrust belt and are less than 0.6 percent vitrinite reflectance near Cutbank field.

The play boundary is defined on the basis of vitrinite reflectance exceeding 0.6 percent regardless of Bakken thickness. The Bakken is present over much of north-central 
Montana but is thermally immature. The Bakken Formation and its equivalent rocks occur at depths between about 1,500 and $6,000 \mathrm{ft}$ in this play.

\section{0.--Northern Great Plains Biogenic Gas, High Potential (modified from original narrative written by Dudley D. Rice and Charles W. Spencer)}

This play is based on better quality Upper Cretaceous clastic reservoirs associated with paleopositive features, such as Bowdoin Dome and the Cedar Creek anticline, and with other shoaling areas where thicker shelf sandstones may occur. These thicker sandstone reservoir areas have higher estimated ultimate recoveries for individual wells. The play limits are based on pinchout of shelf sandstones and siltstones.

Reservoirs are marine-shelf sandstone and siltstone and laminated very fine sandstone, siltstone, and organic-rich shale. Porosity in this play varies from as much as 20 percent to about 6 percent. Average porosity is about 12 percent. Permeabilities to gas at in-situ conditions are less than 0.1 millidarcy.

Source rocks are marine shales interbedded with reservoir rocks. Organic content averages about 2 percent total organic carbon. The source rocks are thermally immature with respect to thermogenic hydrocarbon generation. Methane began to be generated soon after burial as a product of methanogenic bacteria activity. This activity continued as long as temperature, pore space, and availability of $\mathrm{CO}_{2}$ for respiration were adequate.

The Bowdoin area has experienced significant drilling and field growth since gas prices increased in the late 1970's. Other than the presently developed areas, relatively little exploration activity has taken place. These shallow, underpressured, tight gas reservoirs look poor on well logs and do not generally yield gas shows when drilled; hence, they are bypassed when drilling for deeper targets.

\section{1.--Northern Great Plains Biogenic Gas, Moderate Potential (Suffield Block Analog) (modified from original narrative written by Dudley D. Rice and Charles W. Spencer)}

This play uses Alberta Shelf Upper Cretaceous clastic reservoirs as an analog. The play is limited eastward by depth and loss of shelf sandstone and siltstone. It is limited on the west by facies change into conventional reservoirs (shoreline sandstones and continental deposits) and by updip water.

The reservoirs are similar to those in play 2810, except sandstone buildups thicker than $20 \mathrm{ft}$ are not generally expected. Average reservoir porosity ranges from 6 to about 12 percent. Individual sandstone and siltstone laminae may have as much as 25 percent porosity. This porosity can be seen in thin section but cannot be accurately analyzed by conventional core analysis. Source rocks are marine shales interbedded with reservoir rocks. Total organic carbon content averages about 2 percent. The source rocks are thermally immature. Gas is the product of methanogenic bacteria activity. 
The play is relatively unexplored in the United States by wells drilled with a biogenicgas objective. Many wells are being drilled in Canada where the play concepts are now well recognized.

\section{2.--Northern Great Plains Biogenic Gas, Low Potential (modified from original narrative written by Dudley D. Rice and Charles W. Spencer)}

This play encompasses those areas of the shallow biogenic-gas accumulation where Upper Cretaceous marine-shelf sandstone and siltstone sequences are thinner and more poorly developed than in Play 2811. Source rocks are marine shales interbedded with reservoir rocks. Total organic carbon content averages about 2 percent. The source rocks are thermally immature. Gas is the product of methanogenic bacteria activity.

The play is relatively unexplored in the United States by wells drilled with a biogenicgas objective. Many wells are being drilled in Canada where the play concepts are now well recognized.

\section{0.--Bakken Fairway 3111.--Bakken Intermediate 3112.-Bakken Outlying (modified from original narrative written by James W. Schmoker)}

The upper and lower shale members of the Devonian-Mississippian Bakken Formation are extremely rich in organic matter. Organic-carbon content averages 11-12 wt. percent. The organic-matter type is predominantly oil-prone, type II kerogen. Vitrinitereflectance values range from 0.4 percent on the eastern flank of the basin to a maximum of about 1.1 percent, corresponding to present-day depths of about $4,500 \mathrm{ft}$ and $11,000 \mathrm{ft}$, respectively. Available evidence indicates that the Bakken Formation of Montana and North Dakota has generated hundreds of billions of barrels of oil.

In the large region where thermal maturity is sufficient for oil generation, the Bakken Formation forms a continuous, self-sourced reservoir containing an enormous volume of oil in-place. Reservoir quality, measured in terms of matrix porosity and permeability, is poor. Production is controlled by fractures, with the result that production rates and ultimate recoveries of wells exhibit a heterogeneous, "hit or miss" character. Truly dry holes are rare, recovery factors are low, and little water is produced. The reservoir is overpressured.

The overall Bakken play is bounded on the north by the Canadian border (a political rather than geologic boundary), on the east, northwest, and west by thermally controlled limits of oil generation, and on the southwest by the Bakken subcrop. Within this area, the Bakken Formation is oil charged. However, drilling and production data indicate that this entire area cannot be characterized by a single play probability, success ratio, and estimated ultimate recovery probability distribution. Consequently, the overall Bakken play is partitioned into three smaller plays-the Bakken Fairway (along the southwest subcrop), Bakken Intermediate, and Bakken Outlying Plays (3110, 3111 , and 3112, respectively). Qualitatively, overall success decreases from the Fairway play to the Intermediate play to the Outlying play. 
The primary causal geologic factor responsible for the different characteristics of the three plays might be systematically increasing thermal maturity levels, and thus more intense oil generation, toward the southwest. The internal boundary of the Bakken Fairway Play is defined by the vitrinite-reflectance contour of 1.02 percent.

The Antelope field (McKenzie County, North Dakota), in the Bakken Intermediate Play, is on a relatively sharp, southeast-trending anticline. Bakken production from the socalled Sanish Pool of the Antelope field was established in 1953. Typical ultimate recoveries of Sanish Pool wells are considerably higher than those of vertical (and horizontal) wells drilled subsequently in other parts of the Bakken accumulation. However, in the intervening 40 years, no analog to the Sanish Pool has been found. Therefore, data from the Antelope field were excluded from the assessment of the Bakken Intermediate Play on the assumption that additional sweet spots equivalent to the Sanish Pool do not exist.

The success in 1953 of the Antelope field triggered additional exploration, but no analogous sweet spots were found. For many years, Bakken wells were completed sporadically, some as bail-out zones for unsuccessful deeper tests. In the late 1980's, improvements in horizontal-drilling technology and economics helped fuel a horizontal-drilling "boom" along the southwest subcrop (Bakken Fairway Play). Horizontal wells in other parts of the Bakken accumulation have thus far been mostly economic failures. As of July, 1993, 161 vertical Bakken wells (excluding the Sanish Pool) have produced 10,320,000 barrels of oil, and 202 horizontal wells have produced $12,233,000$ barrels of oil.

Portions of the Bakken Fairway Play have reached a mature stage of development. However, considering the Bakken accumulation as a whole, many thousands of square miles that are likely underlain by moveable oil remain undrilled. The Bakken accumulation is far from exhausted. Production will be controlled by fractures and will be relatively unpredictable on a well-by-well basis. Producing depths will be between $8,500 \mathrm{ft}$ and $11,000 \mathrm{ft}$.

\section{3.--Southern Williston Basin Margin - Niobrara Shallow Biogenic (modified from original narrative written by J.W. Schmoker)}

Shallow chalk units of the Upper Cretaceous Niobrara Formation have potential for the generation and retention of biogenic gas, which is generated at low temperatures by bacterial breakdown of organic material in an anaerobic environment. This play addresses the potential for Niobrara biogenic gas production along the southern flank of the Williston Basin. Niobrara chalk reservoirs, source rocks, and structural influences in the southern Williston Basin margin are similar to those of commercially productive areas in the eastern flank of the Denver Basin. Porosities are high, organic-carbon content is adequate for gas generation, and shows of biogenic gas have been reported. The close association between source and reservoir rocks, large areal extent, abundant gas shows, low matrix permeability, and abnormal (low) reservoir pressure of the analog eastern Denver Basin Niobrara production are characteristics typical of a selfsourced, continuous-type gas accumulation. 
The boundary of play 3113 encloses a 30,000 sq mi area having the best likelihood for biogenic gas within a much larger area of biogenic-gas potential in North Dakota and South Dakota. The geologic factors that combine to make the area of play 3113 conceptually more favorable are the presence of two chalk units, net chalk thickness exceeding $100 \mathrm{ft}$, minimal Niobrara outcrop or subcrop, depth of burial of about 1,000 ft, and moderate post-depositional structure development. The area of the Goodland field (northwestern Kansas) is an analog for Niobrara production parameters in the southern Williston Basin because depths of burial and strata at the top of the Niobrara are similar.

Production of biogenic gas from chalk of the Niobrara Formation is solidly established elsewhere, and the geologic setting of the Niobrara in the southern Williston Basin margin is similar to that of producing areas. Gas in place within the play area has been estimated at 21 trillion cubic feet. On the negative side, production has not been established in the play area.

\section{8.--Mowry Fractured Shale (modified from original narrative written by Gordon $L$.} Dolton and James E. Fox)

This play is defined by the occurrence of oil and gas in highly fractured Upper Cretaceous Mowry Shale reservoirs in the deep parts of the Powder River Basin. The shale is considered both a reservoir and a source. The play occupies a $10,000 \mathrm{sq}$ mi area of thermally mature Mowry Shale in the central part of the basin.

Controls on the origin and distribution of fracturing in the shale are not certain but appear related to geopressuring associated with thermal maturation of the organic matter and attendant phase and volume changes. Tectonic controls play a secondary role. The organic-rich Mowry Shale contains a mixture of type II and III organic matter. Hydrocarbons accumulated contemporaneously with fracture development.

No known purposeful exploration has taken place in this play; however, at least six fields in the deeper parts of the basin have shown production from fractured Mowry Shale, usually in conjunction with productive Muddy Sandstone. A large quantity of in-place hydrocarbons may exist. Data are insufficient to permit a satisfactory assessment of recoverable resources.

3311.-Niobrara Fractured Shale (modified from original narrative written by Gordon $L$. Dolton and James E. Fox)

This play is defined by the occurrence of oil and associated gas principally in fractured shale reservoirs of the Upper Cretaceous Niobrara Formation. Controls on fracturing are not well understood. In some instances, fractures appear localized or enhanced on structural flexures and faults. Geopressuring associated with thermal maturation of the organic matter and attendant phase and volume changes have been proposed as a causative factor. Distribution of thermally mature Niobrara Shale and of fracturing is not well known.

The organic-rich Niobrara Shale is considered both reservoir and source. The Niobrara is amenable to horizontal drilling techniques, for which Silo field in the nearby Denver 
Basin is considered a geologic and development analog. Conventional drilling has produced modest amounts of Niobrara oil at West Salt Creek and Smokey Gap in the Powder River Basin, and a small amount of production from Niobrara exists in deep parts of the basin. However, the play remains virtually unexplored. Data are insufficient to permit a satisfactory assessment of recoverable resources.

\section{4.--Basin-Center Gas (modified from original narrative written by James E. Fox and Gordon L. Dolton)}

This play in deep parts of the Big Horn Basin is characterized by gas trapped in an extensive basin-center accumulation in sandstones of Paleocene and uppermost Cretaceous age. Reservoirs are overpressured due to active generation of gas. Older Cretaceous rocks, which may also be geopressured, were not included in the play because of their generally thin reservoir development and limited reservoir volume. This play is defined vertically by a vitrinite-reflectance level of 1.0 percent at the top of the involved section, which corresponds approximately to a burial depth of $12,000 \mathrm{ft}$.

Reservoirs are generally lenticular arkosic or lithic sandstones of fluvial origin with poor to modest porosity and low permeability. Some more blanket-like marine sandstones also are present. Reservoirs occur within the Fort Union, Lance, Meeteetsee, and Mesaverde intervals. The overall sequence has significant internal compartmentalization. Source rocks include associated humic-rich rocks and coals. Gas appears to be thermogenic, with some vertical migration possible. Overpressuring due to active generation of gas generally coincides with vitrinite reflectance of 1.0 percent or more.

This play has seen virtually no exploration and is speculative in nature. Field development has not yet taken place. Potential for gas accumulations is good. Due to lack of data and tentative characterization of the play, no quantitative assessment was made.

\section{5.-Basin-Center Gas (modified from original narrative written by James E. Fox and Gordon L. Dolton)}

This play in the Wind River Basin is characterized by an extensive and continuous overpressured gas accumulation trapped in low permeability Paleocene and uppermost Cretaceous sandstone reservoirs in deep parts of the basin. Overpressuring is due to active generation of gas. Older Cretaceous rocks, which may also be geopressured, are not included in the play because of their generally thin reservoir development and limited reservoir volumes.

Principal reservoirs are fluvial and marine sandstone beds in the Fort Union, Lance, and Mesaverde Formations. These reservoirs are generally arkosic or lithic, with poor to modest porosity and low permeability. The overall sequence displays significant internal compartmentalization. Source rocks are associated humic-rich rocks and coals, with some contribution possible from underlying Cretaceous units. Gas appears to be thermogenic. Overpressuring generally coincides with vitrinite reflectance of 1.0 
percent or more, which defines the top of the play. Depth to the top of the play is approximately $10,000 \mathrm{ft}$.

This play has seen virtually no meaningful exploration and is speculative in nature. Field development has not yet taken place. The resource potential is uncertain and was not quantitatively assessed.

\section{0.--Greater Green River Basin - Cloverly-Frontier (modified from original narrative written by Ben E. Law)}

This play encompasses an area of about $12,500 \mathrm{sq} \mathrm{mi}$. The play area includes all of the overpressured, deeper parts of the Greater Green River Basin in Wyoming and Colorado. Along the Moxa Arch, in the western part of the Green River Basin, Lower Cretaceous Dakota and equivalent rocks are excluded; these rocks have been assessed as conventional reservoirs in the Moxa Arch-LaBarge Play (3704). The Greater Green River Basin - Cloverly-Frontier Play includes the Upper Cretaceous strata in the interval from the base of the Cloverly and equivalents to the top of the Frontier Formation. Individual sandstone reservoirs in the play range in thickness from 10 to $70 \mathrm{ft}$. The depth of reservoirs is highly variable, ranging from 10,000 to $20,000 \mathrm{ft}$.

Sources of gas are coal and carbonaceous shale in the Cloverly and Frontier and shale in the Mowry. Because gas is generated within, or in close proximity to reservoirs in basin-centered gas accumulations, temporal relationships between generation, migration, and development of a trap are not nearly as important as in conventional gas accumulations. Burial and thermal reconstructions suggest that gas generation might have begun during late Eocene time.

Along the Moxa Arch, the play is currently experiencing a large amount of drilling. Elsewhere in the play area where drilling depths exceed $16,000 \mathrm{ft}$, uncertainties exist concerning the quality of matrix and fracture permeability. However, with the advent and application of new drilling and completion techniques, reservoirs in the deeper parts of the play might prove to be economically productive.

\section{1.--Greater Green River Basin - Mesaverde (modified from original narrative written by Ben E. Law)}

This play encompasses an area of about 8,200 sq mi in Wyoming and Colorado. The play area extends through the deeper parts of the Great Divide, Washakie, and Sand Wash Basins and the northern part of the Green River Basin. The Greater Green River Basin - Mesaverde Play includes the Upper Cretaceous stratigraphic interval from the base of the Rock Springs Formation and equivalent rocks to the top of the Almond Formation in the Great Divide, Washakie, and Sand Wash Basins. West of the Rock Springs Uplift, in the Green River Basin, the play includes the stratigraphic interval from the base of the Rock Springs Formation and equivalent rocks to the top of the Ericson Sandstone. The thickness of the stratigraphic interval ranges up to $5,000 \mathrm{ft}$, and the cumulative thickness of reservoirs ranges from less than 750 to 2,000 ft. Individual 
reservoirs range in thickness from 10 to $75 \mathrm{ft}$. The depth to the top of reservoirs in the Mesaverde Play ranges from 8,000 to $18,000 \mathrm{ft}$.

The most likely source rocks are coal and carbonaceous shale within the play interval. Gas began to be generated from the Mesaverde in late Eocene or Oligocene time. Like all basin-centered gas accumulations, traps and seals as visualized in conventional hydrocarbon accumulations are not of fundamental importance.

The play is immaturely explored with the exception of Almond Formation reservoirs in the Washakie Basin, where several fields produce gas from the uppermost part of the Almond. The Almond production represents "sweet spots" where reservoir quality is better than the rest of the Mesaverde reservoirs. Most of this play remains unevaluated.

3742.--Greater Green River Basin - Lewis (modified from original narrative written by Ben E. Law)

This play includes the stratigraphic interval of the Upper Cretaceous Lewis Shale. The play area encompasses about 3,900 sq mi and is restricted to the deeper parts of the Great Divide, Washakie, and Sand Wash Basins in Wyoming and Colorado. The western boundary of the play coincides with the western edge of the Lewis Shale transgression. Reservoirs occur as isolated sandstones bounded above and below by shale. The cumulative thickness of reservoirs in the play ranges from less than $200 \mathrm{ft}$ to inore than $600 \mathrm{ft}$ and the median thickness is $400 \mathrm{ft}$. Individual sandstone reservoirs range in thickness from 10 to $100 \mathrm{ft}$. Depth to the top of reservoirs in the Greater Green River Basin - Lewis Play ranges from 8,000 to $14,000 \mathrm{ft}$. Sources of gas are the marine shales of the Lewis Shale. Gas began to be generated in Oligocene time.

The play is moderately explored. Several fields produce from low-permeability reservoirs within the play. However, a large area is undrilled and untested.

\section{3.--Greater Green River Basin - Fox Hills-Lance (modified from original narrative written by Ben E. Law)}

This play includes the Upper Cretaceous stratigraphic interval from the base of the Fox Hills Sandstone to the top of the Lance Formation. In the Green River Basin, the play includes the interval from the top of the Ericson Sandstone to the top of the Lance Formation. The play area encompasses about 4,100 sq $\mathrm{mi}$ in the northern part of the Green River Basin and in the deeper parts of the Great Divide, Washakie, and Sand Wash Basins of Wyoming and Colorado. The reservoirs in the Fox Hills part of the play are deltaic sandstones. In contrast, reservoirs in the Lance part of the play were deposited in fluvial-dominated systems and are more lenticular than those in the Fox Hills. The cumulative thickness of reservoirs in the play ranges from less than $250 \mathrm{ft}$ to greater than $1,500 \mathrm{ft}$, with a median of $675 \mathrm{ft}$. Individual reservoirs range in thickness from 10 to $100 \mathrm{ft}$. The depth to the top of reservoirs within the play ranges froin 8,000 to $12,000 \mathrm{ft}$. Sources of gas are coal and carbonaceous shale in the Fox Hills Sandstone and Lance Formation. 
The play is immaturely explored. Through nearly all of the play, reservoirs have been very sparsely tested.

\section{4.--Greater Green River Basin - Fort Union (modified from original narrative written by Ben E. Law)}

This play interval encompasses the Paleocene Fort Union Formation. However, basincentered gas accumulations in the Fort Union appear to be restricted to approximately the lower half of the formation. The play encompasses an area of about $520 \mathrm{sq} \mathrm{mi}$ and is limited to the deepest part of the Washakie Basin, Wyoming. Reservoirs in the play are composed of lenticular sandstone deposited in fluvial-dominated systems. The cumulative thickness of reservoirs ranges from less than $500 \mathrm{ft}$ to more than $1,500 \mathrm{ft}$ and the median thickness is $600 \mathrm{ft}$. Individual reservoirs range in thickness from 10 to $80 \mathrm{ft}$. The depth to the top of basin-centered gas accumulations ranges from 9,000 to $9,500 \mathrm{ft}$. Sources of gas are coal and carbonaceous shale in the Fort Union Formation.

The play is immaturely explored. The objective of most wells drilled in the Washakie Basin has been the Almond or Lewis. Gas accumulations in the Fort Union have been bypassed, perhaps because of the more laterally continuous reservoirs in the Almond as well as the historical success of production from the Almond and Lewis.

\section{3.--Upper Cretaceous Niobrara Fractured Shale Oil (modified from original narrative written by Richard M. Pollastro)}

The Niobrara ranges in thickness from about $500 \mathrm{ft}$ in South Park Basin to as much as $800 \mathrm{ft}$ in North Park Basin, and varies in lithology from fissile-bedded, dark gray calcareous shale to more brittle micritic limestone and marl. Burial-history reconstructions in North Park indicate maximum burial depths near 20,000 ft.

The Niobrara Formation produces some oil and gas in fields of the North Park Basin from fractured calcareous shale or marl. In the Middle and South Park Basins, no commercial Niobrara production has been reported. Cumulative production from fractured Niobrara in the North Park Basin as of July, 1993, was about 250 thousand barrels of oil.

Prolific, self-sourced oil is produced from fractured, cyclic-bedded, organic-rich units of the Niobrara in the northeastern portion of the Denver Basin to the east and along the eastern portion of the Sand Wash Basin to the west. The Niobrara in the Park Basins could also have good petroleum potential assuming favorable burial conditions and favorable reservoir elements for oil production. Cuttings from the Hunt Oil Company Federal No. 1-17 Tarryall well, Park County, in South Park Basin from depths of 5,600 ft to $12,700 \mathrm{ft}$ have vitrinite-reflectance values ranging from 0.5 to 1.5 percent and total organic carbon contents ranging from 0.1 to $1.5 \mathrm{wt}$. percent. Although some oilgenerating potential is evident from the burial history and geochemical analysis of the Niobrara in various areas of the province, no additional fractured reservoir systems have been identified. 
3904.--Greater Wattenberg Codell/Niobrara Oil and Gas (modified from original narrative written by Debra K. Higley, Richard M. Pollastro, and Jerry L. Clayton)

Oil and gas of this play are trapped in marine sandstones of the Upper Cretaceous Codell Sandstone (Wall Creek/Turner equivalents) and in cyclically-bedded chalk, marl, and shale of the Niobrara Formation. The Codell and Niobrara are evaluated together because many wells report co-mingled production. Reservoir sandstones exhibit low porosity and permeability and are classified as tight gas sands. Productive depths are about $3,000-8,000 \mathrm{ft}$. Average depth is $6,800 \mathrm{ft}$. Niobrara Formation thickness ranges from 240 to $330 \mathrm{ft}$; four $20-30 \mathrm{ft}$ thick chalk zones in the unit are productive. Thickness of reservoir sandstones ranges from 22 to $35 \mathrm{ft}$.

Source rocks are probably the organic-rich Cretaceous Mowry, Graneros, and Niobrara Formations. Thermal-maturity data from the underlying Mowry and Graneros Shales suggest vitrinite-reflectance levels of 0.8 percent and greater in the play area.

Basin center Codell/Niobrara producing areas with ultimate gas recoveries greater than 6 billion cubic feet include Bracewell, Eaton, Greeley, Kersey, and Wattenberg.

Additional producing areas may be developed through northward extension of deep basin gas exploration.

3906.-J Sandstone Deep Gas (Wattenberg) (modified from original narrative written by Debra K. Higley, Richard M. Pollastro, and Jerry L. Clayton)

This play is located in the deepest areas of the Denver Basin in Colorado and Wyoming. Gas is produced from fine-grained quartz arenites of nearshore marine sandstones of the Fort Collins Member of the Lower Cretaceous Muddy (J) Sandstone and, to a lesser extent, from distributary channel sandstones of the Horsetooth Member of the J sandstone. Porosity and permeability range from 8 to 12 percent and 0.01 to 5 millidarcies and average 9.5 percent and 0.05 millidarcy, respectively. Thickness of reservoir intervals averages $20 \mathrm{ft}$. Reservoirs are underpressured and produce from depths of about $7,200-8,500 \mathrm{ft}$.

Vitrinite-reflectance values from 1.1 to 1.75 percent in the area of the Wattenberg field, combined with carbon stable isotope data, suggest that the gas has a thermogenic origin. Gas generation in the play area began during middle to late Tertiary time. Total organic carbon values average about 2.5 percent by weight for the Graneros, Mowry, and Skull Creek Shales, which are source rocks for the play.

The Wattenberg area, in Weld County, Colorado, has produced 487 billion cubic feet of gas and has proved gas reserves of 1.3 trillion cubic feet. The Wattenberg field was discovered in 1970. Additional reserves will result primarily from growth and extension of the Wattenberg field. The deep lobe of the Denver Basin in Wyoming does not have equivalent gas production. However, exploration has been very limited, and some potential for deep gas exists. 


\section{1.--Fractured Shale - Pierre (modified from original narrative written by Debra K. Higley and Donald L. Gautier)}

Oil in this play is produced from underpressured, relatively impermeable shales of the Upper Cretaceous Pierre Shale in the Florence field. Reservoir facies are gray to black organic-rich shales, and thin sandy shales. The Pierre Shale in Florence field is about $100 \mathrm{ft}$ thick. Depths of production range from about 900 to 2,600 ft. Maximum field size is 22,000 acres.

Most of the tectonic and sedimentologic factors important in forming Niobrara continuous-type fractured reservoirs are also present within the Pierre shales--that is, presence of open fractures, organic-rich shales as an in-place source of oil, and brittle reservoir rocks. Underlying shales limit influx of water into the Pierre reservoir. Drive mechanism at Florence field is gravity drainage with minor solution gas drive; initial field pressure was 5-10 psi.

The Florence field was discovered in 1862 and is the oldest continuously producing field in the world. About 15 million barrels of oil were produced through 1990 from fractured Pierre shales. Ultimate oil recovery is estimated at 15.5 million barrels. Potential is low for additional significant fractured Pierre Shale discoveries, although small discoveries in other areas of the province are possible.

\section{0.--Fractured Niobrara - Greater Silo/Dale Salt-Edge Oil (modified from original narrative written by Debra K. Higley, Richard M. Pollastro, and Jerry L. Clayton)}

This play in the Denver Basin lies exclusively in Laramie County, Wyoming, and encompasses two fields. Silo field represents a "sweet spot" for fracture production. Dale field directly to the east has essentially merged with Silo. Oil is produced from organic-rich, underpressured and fractured, cyclically-bedded chalk, marl, and calcareous shale of the Upper Cretaceous Niobrara Formation. These micritic limestones have matrix permeability of less than 0.01 millidarcy and typical matrix porosity of 6-8 percent.

Open vertical fractures (with coexisting vertical stylolites) form the reservoir at Silo. These fractures formed under compression by wrench faulting and are enhanced along an irregular salt-solution edge in Lower Permian rocks. Oils are sourced from organicrich (up to $6 \mathrm{wt}$. percent total organic carbon) beds in the upper Smoky Hill Member of the Niobrara. Kerogens are primarily oil-prone algal type II. Niobrara source beds probably reached thermal maturity beginning in the Late Cretaceous. The play boundary lies within an area of thermal hydrocarbon generation estimated from thermal maturity indicators and along a fracture trend that approximates the Permian salt edge.

Horizontal drilling at Silo field began in 1990. Cumulative oil production for all wells through July, 1993 was 3.14 million barrels. Oil recovery from average horizontal wells at Silo is about two and a half times that from average vertical wells. Production in the Silo/Dale area is entirely from the Niobrara with most from the middle chalk unit or chalk "bench", informally designated as the "B bench". Some vertical-well production 
has also come from the lowest chalk unit in the Smoky Hill Member, the "C bench". Pay thickness in the "B bench" ranges from 25 to $35 \mathrm{ft}$. This principal target zone is commonly traced as a continuous unit in geophysical logs and correlates to maximum resistivity and mimimum gamma ray intensity.

\section{1.--Fractured Niobrara - Greater Northern Denver Basin Oil (modified from original narrative written by Debra K. Higley, Richard M. Pollastro, and Jerry L. Clayton)}

Oil produced from the fractured Upper Cretaceous Niobrara Formation is commonly co-mingled with that produced from the underlying fractured Upper Cretaceous Codell Sandstone in the greater Denver Basin. This play excludes the area outlined by the Fractured Niobrara - Silo/Dale Salt-Edge Oil Play (3920), southeastern Wyoming, and lies north of the Greater Wattenberg Codell/Niobrara Oil and Gas Play (3904). The east and west boundaries of the play are defined by a combination of thermal maturity indicators (vitrinite reflectance of about 0.7 percent), structure, and production history.

Fractures in the Niobrara appear to be present throughout the northern Denver Basin as suggested by lineaments mapped by Landsat imagery and by seismic data. Oil production in the play area is mostly from small isolated fields or wells. This play is probably best represented by the wells in the region having low to moderate cumulative oil production ranging from a few thousand to 30,000 barrels.

\section{REGION 5--WEST TEXAS AND EASTERN NEW MEXICO}

4503.--Mississippian Barnett Shale (modified from original narrative written by Mahlon $M$. Ball and William J. Perry, Jr.)

The organic-rich Mississippian Barnett Shale is both the reservoir and source rock for this play. Production of 34.5 billion cubic feet of gas through 1990 occurred in a single field, Newark East, in southwest Wise County. Reservoir permeability is probably less than 0.1 millidarcy. Typical reservoir depth is $7,000 \mathrm{ft}$. The limits of the play encircle the single known petroleum occurrence and were drawn simply to acknowledge the broad distribution of the reservoir facies in the province. Risk for additional producible discoveries in this play is high but potential for additional discoveries is also significant.

\section{REGION 6--GULF COAST}

4747.--Austin Chalk - Pearsall (modified from original narrative written by Christopher J. Schenk and Roland J. Viger)

This play was developed to estimate recoverable oil resources in a section of the middip Upper Cretaceous Austin Chalk trend centered around the Pearsall area. The play is bounded updip by conventional Austin Chalk plays and is located in parts of Dimmit, Zavala, Frio, La Salle, Atacosa, Wilson, Karnes, Gonzales, and Lavaca counties, Texas. The reservoir rock in this play is coccolith- and foraminifera-bearing fractured chalk. Reservoir quality is dependent upon the intensity of fracturing. Depths of untested reservoir cells range from 5,000 to 11,000 feet. 
Sources for the oil and gas in the Austin Chalk are interpreted to be micrites within the Austin, particularly in the deeper parts of the play, and mudstones of the Upper Cretaceous Eagleford Formation. The mid-dip area of the Austin Chalk does not contain large structures associated with fault zones, but the Pearsall area does have a large, subtle domal structure that might have served to focus fracturing. Fractured chalk reservoir rock appears to be intercalated with shales and marls that did not fracture like the chalk; fractured chalk might be sealed by non-fractured shale and marl.

The recoverable oil resource in the Austin Chalk in the greater Pearsall area is estimated to be approximately twice the volume of oil that has already been produced. Although not assessed using fields, the Pearsall, Horn, Pilgrim, Sutil, Mag, Cost, Marcelina Creek, Peach Creek, Cindy Ann, Pandora Northwest, and First Shot fields are included in the play area.

\section{8.--Austin Chalk - Giddings (modified from original narrative written by Christopher J. Schenk and Roland J. Viger)}

This play was developed to assess the recoverable oil resources in a section of the middip Austin Chalk trend centered on the Giddings area. The play is bounded updip by conventional Austin Chalk plays and is located in parts of Fayette, Bastrop, Lee, Washington, Burleson, Brazos, and Grimes counties, Texas. The reservoir rock in this play is coccolith- and foraminifera-bearing fractured chalk. Reservoir quality is dependent upon the intensity of fracturing. Depths of untested reservoir cells range from 6,000 to 12,000 feet.

Sources for the oil and gas in the Upper Cretaceous Austin Chalk are interpreted to be micrites within the Austin, particularly in the deeper parts of the play, and mudstones of the Upper Cretaceous Eagleford Formation. The mid-dip area of the Austin Chalk does not contain large structures associated with fault zones. Unlike the greater Pearsall area, the Giddings area might not have a large, subtle structure that served to focus fracturing. Fractured chalk reservoir rock appears to be intercalated with shales and marls that did not fracture like the chalk; fractured chalk might be sealed by nonfractured shale and marl.

The Austin Chalk in this play is estimated to contain a mean recoverable oil resource about equal to that already produced. Although this play was not assessed using fields, the Giddings, Clay Northeast, Kurten, Woodbine, Caldwell, Stone City, Big-A-Taylor, and Jerry's Quarter's fields are included in the play area.

4749.--Austin Chalk - Outlying (modified from original narrative written by Christopher J. Schenk and Roland J. Viger)

This play is bounded updip by conventional Austin Chalk plays and is separated into northeastern and southwestern parts by the Austin Chalk - Pearsall and Austin Chalk Giddings Plays (4747 and 4748). The Austin Chalk - Outlying Play is located in parts of Webb, Dimmit, Maverick, and Zavala counties in the southwest area and in parts of Angelina, Trinity, Polk, Jasper, Newton, Tyler, Walker, Houston, Leon, Madison, 
Robertson, Milam, Burleson, Lee, and Bastrop counties, Texas, and Sabine, Vernon, Rapides, and Avoyelles counties, Louisiana, in the northeast area. The reservoir rock in this play is coccolith- and foraminifera-bearing fractured chalk. Reservoir quality is dependent upon the intensity of fracturing. Depths of untested reservoir cells range from 7,000 to 12,000 feet.

Sources for the oil and gas in the Austin Chalk are interpreted to be micrites within the Austin, particularly in the deeper parts of the play, and mudstones of the Eagleford Formation. The mid-dip area of the Austin Chalk does not contain large structures associated with fault zones. Unlike the greater Pearsall area, the outlying areas might not have large, subtle structures that served to focus fracturing. Fractured chalk reservoir rock appears to be intercalated with shales and marls that did not fracture like the chalk; fractured chalk might be sealed by non-fractured shale and marl.

The Austin Chalk in this play is estimated to contain a mean recoverable resource of about 200 million barrels of oil. Although this play was not assessed using fields, Elaine, Cherokee, and Brookeland fields are included in the play area.

\section{3.--Cotton Valley Blanket Sandstones Gas (modified from original narrative written by Christopher J. Schenk and Roland J. Viger)}

This play is defined by sandstones of the Upper Jurassic Cotton Valley Group that produce gas from a narrow east-west trend south of the North Louisiana Stateline Graben System. The play boundary corresponds to depositional limits of the blanket sandstones. Reservoirs in this play are fluvial-deltaic sandstones of the Cotton Valley Group, including sandstones known locally as the Bodcaw, Vaughan, Taylor, Davis, and Sexton. The porosity of the sandstones ranges up to 20 percent, and permeabilities range up to 250 millidarcies. Depths of untested cells in this play range from 7,000 to $12,000 \mathrm{ft}$.

The gas is derived from mudstones of the lower part of the Upper Jurassic Smackover Formation and/or from mudstones within the Cotton Valley Group. The gas migrated up faults from the Smackover or updip from deeper mudstones of the Cotton Valley.

This play contains 25 gas reservoirs discovered between 1936 and 1977. Given the extensive exploration history and level of exploration in this play, the potential for undiscovered sweet spots is estimated to be moderate, but significant reserve additions will be generated by the expansion and coalescing of existing producing areas.

\section{REGION 7--MIDCONTINENT}

\section{1.--Woodford/Chattanooga/Arkansas Novaculite of Midcontinent (modified from original narrative written by James W. Schmoker)}

This play addresses the possibility that one or more continuous-type oil or gas accumulations exist in the Mississippian and Devonian Woodford Shale and equivalents of the Midcontinent Region. The play encompasses the Oklahoma portion of the Anadarko Basin, the Southern Oklahoma Fold Belt, the Arkoma Basin, the 
Oklahoma portions of the Nemaha Uplift and Cherokee Platform, and possibly parts of the Permian Basin.

Total thickness of the Woodford in the Anadarko Basin ranges from near zero to about $125 \mathrm{ft}$ on the northeast shelf and increases to more than $900 \mathrm{ft}$ in limited areas of the deep basin. Organic-carbon content averages about $5 \mathrm{wt}$. percent on the northeast shelf. Vitrinite-reflectance values range from 0.5 percent at present depths of roughly $5,000 \mathrm{ft}$ to well over 2.0 percent at present depths exceeding $20,000 \mathrm{ft}$.

In addition to the Anadarko Basin, the Woodford is present in eastern Oklahoma, the Southern Oklahoma Fold Belt, and the Arkoma Basin. The Woodford becomes more siliceous to the southeast where it grades into the Arkansas Novaculite. In Kansas, where organic-carbon content is typically above source-rock minimums but levels of thermal maturation appear to be at or below the onset of hydrocarbon generation, the equivalent formation is commonly called the Chattanooga Shale, and this terminology is sometimes extended southward into eastern Oklahoma.

Two lines of reasoning support the concept of Woodford and equivalents continuoustype accumulations. The first assumes that the well-established Bakken continuous-type accumulation of the Williston Basin is an analog. The second is based on resistivity logs of the Woodford Shale in the Anadarko Basin. If Woodford resistivity values greater than $35 \mathrm{ohm}$-meters are interpreted as indicating the presence of internally generated oil or gas, a considerable area of the Woodford Shale could be charged with hydrocarbons.

Petroleum exploration within the play area has generally reached a mature stage, and a continuous-type accumulation has not been confirmed. Fields known to have Woodford production, such as Isom Springs, Sho-Vel-Tum, and Caddo appear to be structurally controlled, conventional accumulations. However, exploration has been directed toward conventional structural and stratigraphic traps. The possibility remains that a continuous-type accumulation exists but has not been recognized.

\section{REGION 8--EASTERN}

\section{9.--Antrim Shale Gas, Developed Area \\ 6320.--Antrim Shale Gas, Undeveloped Area (modified from original narrative written by Gordon L. Dolton)}

These plays are based on gas within the fractured Antrim Shale of Late Devonian age. The play includes parts of the Ellsworth Shale in western Michigan and Bedford Shale in eastern Michigan. The play is bounded to the west by the low organic content of the Ellsworth Shale and the loss of thick organic-rich Antrim Shale tongues. Organic maturity of the Antrim Shale is sufficient to have generated hydrocarbons within the central Michigan Basin. Production probably is feasible only where the shales are sufficiently fractured. Principal development of the play to date is in Antrim, Otsego, and Montmorency Counties, and to a lesser extent, Kalkaska, Crawford, and Oscosa Counties. 
The formation is as thick as $800 \mathrm{ft}$ and fractured shales provide reservoirs and conduits for production. Gas is sorbed within the shale, dissolved in bitumen, and stored in matrix porosity. The "black facies" of the Antrim Shale has a total organic carbon content ranging from less than 1 to 25 percent, averaging about 8 percent. The shales are well within the oil generative window at depths greater than $2,500 \mathrm{ft}$. Generation of hydrocarbons probably began in Pennsylvanian time during subsidence of the basin.

Controls of fracturing are not well understood and have been attributed to tectonism, flexuring over underlying Silurian reefs, differential loading by glacial drift, and dilation due to glacial unloading. Economic recovery of gas is mostly confined to Upper Black and Lower Black (Lachine and Norwood Members) shale facies of the Lower Antrim, capped by Upper Antrim and Middle gray (Paxton Member) beds, respectively.

Production depth generally ranges between 1,200 and $2,000 \mathrm{ft}$ but is reported as almost $2,600 \mathrm{ft}$ in Crawford County and as 3,200 ft in Missaukee County. Production at Otsego Field began in 1940, but intensive development in the play has occurred since 1986. Well production typically ranges from 25 to 150 thousand cubic feet of gas per day. Scattered gas wells are recorded in Missaukee, Wexford, and Jackson Counties. Although the in-place resource potential of these plays may be large, economic deliverablility of the resource is very poorly understood.

\section{7.--Illinois Basin - New Albany Shale Gas (modified from original narrative written by Joseph R. Hatch)}

This is a continuous-type play because (1) the reservoir is low-permeability fractured shale, (2) the shale is the source of the hydrocarbons, (3) formation pressure is abnormally low, (4) gas shows or production occur in most holes drilled, and (5) structural control is lacking. The play is defined as the area where organic-matter-rich facies in the New Albany Shale in the southeastern part of the Illinois Basin have vitrinite-reflectance values exceeding 0.6 percent. The New Albany Shale in westcentral Illinois is not included in the play area because the dominant lithology is organic-lean, bioturbated greenish-gray and olive-gray shale.

The New Albany Shale, present throughout the Illinois Basin in Illinois, Indiana, and western Kentucky, ranges from Middle Devonian through Kinderhookian (Early Mississippian) in age. In southeastern Illinois and adjacent western Kentucky, the New Albany Shale is more than $460 \mathrm{ft}$ thick. The shale thins toward the basin margins except in west-central Illinois where thicknesses greater than $300 \mathrm{ft}$ are reported in Henderson and Hancock Counties. Maximum potential for New Albany Shale gas production is in regions interior to the Moorman Syncline in western Kentucky and in areas of Illinois and Indiana where the lack of surface faulting increases the potential for maintaining a seal to the gas accumulations.

The source of the gas in the fractured New Albany Shale reservoirs is the New Albany Shale itself. Organic carbon contents range from less than 1 to 15.6 percent. Vitrinite-reflectance and liptinite-fluorescence measurements reveal a regionally 
consistent pattern of increasing maturation southward toward the area of greatest paleoburial depth and (or) higher heat flow. Organic maturation levels are highest in southeastern Illinois and adjacent western Kentucky and are within the uppermost zone of oil generation.

Relatively small amounts of natural gas have been produced from this play along the southeastern border of the basin. Of 30 producing areas, 21 were discovered as a result of high gas prices in the late 1970's.

6604.--Devonian Black Shale Gas (modified from original narrative written by Robert $T$. Ryder and Joseph R. Hatch)

This play is defined by gas generated and trapped in fractured black shale of the Upper Devonian Chattanooga and New Albany Shales. The play extends across the Cumberland Saddle and adjoining flanks of the Jessamine (Lexington) and Nashville Domes. The play is characterized as continuous-type because (1) the reservoir is lowpermeability, fractured black shale, (2) gas is derived locally from the black shale, (3) formation pressure is abnormally low, and (4) gas shows or production occur in most holes drilled.

The reservoir is fractured black shale in the Chattanooga and New Albany Shales. The fractured reservoirs are self-sourced. The thickness of the Chattanooga Shale in the Cumberland Saddle and eastern flank of the Jessamine (Lexington) Dome ranges from 25 to $50 \mathrm{ft}$. The New Albany Shale on the west flank of the Jessamine(Lexington) Dome is slightly thicker. Total organic carbon values of the Chattanooga and New Albany Shales in the play area range from about 7 to 16 percent. The Chattanooga Shale in the Cumberland Saddle is in the beginning of the zone of oil generation. The Chattanooga and New Albany Shales on the flanks of the Jessamine (Lexington) Dome are thermally immature.

Oil and gas probably were initially generated in Late Pennsylvanian to Early Triassic time. The oil migrated into overlying and underlying carbonate reservoirs, whereas much of the gas was adsorbed on fracture faces, clay particles, and kerogen particles and remained near its point of origin.

Drilling depths to the Chattanooga and New Albany Shales range from about 250 to $1,500 \mathrm{ft}$. Between 5,000 and 10,000 holes have been drilled into or through the play. However, most of these drill holes are not considered to be tests of the play because they were intended for deeper objectives. Since 1890, about 12 small gas fields have been discovered in the Chattanooga and New Albany Shales in the play area. This play has potential for a relatively small amount of undiscovered gas. The low level of thermal maturity attained by the Chattanooga and New Albany Shales in the play area is a risk factor. 


\section{8.--Clinton/Medina Sandstone Gas High Potential \\ 6729.--Clinton/Medina Sandstone Gas Medium Potential \\ 6730.--Clinton/Medina Sandstone Gas Medium-Low Potential \\ 6731.--Clinton/Medina Sandstone Gas Low Potential(modified from original narrative written by Robert T. Ryder)}

The conventional Tuscarora Sandstone Gas Play (6727), continuous-type Clinton/Medina Sandstone Gas plays $(6728,6729,6730,6731)$, and conventional Clinton/Medina Sandstone Oil/Gas Play (6732) are contiguous plays that occupy progressively westward areas of the Lower Silurian sandstone depositional system in the Appalachian Basin. Most of the sandstone was deposited in littoral-marine, deltaic, and offshore-marine settings. This group of plays extends westward from near the Allegheny structural front in Pennsylvania, West Virginia, and Virginia, where sandstone beds are thickest, to the depositional limit of the Lower Silurian Clinton sandstone in east-central Ohio and eastern Kentucky, where sandstone beds are thinner and intercalated with abundant shale and siltstone. The Lower Silurian sandstone system extends into New York as far north as the outcrop limit of the Lower Silurian Medina Group and as far east as the subcrop of the Tuscarora Sandstone beneath the Middle Silurian Oneida Sandstone.

The Clinton/Medina Sandstone Gas plays are characterized as continuous-type because of low-permeability reservoirs, abnormally low formation pressure, coalesced gas fields, gas shows or production in most holes drilled, and general lack of control by anticlinal closure. Four Clinton/Medina Sandstone Gas plays are recognized according to their estimated potential for undiscovered gas resources. The high potential play (6728) is down-dip of the conventional Clinton/Medina Sandstone Oil/Gas Play (6732). The two parts of the low potential play (6731) mark the extreme northern and southern ends of the proposed continuous-type accumulation. On the east side the plays are bounded by an arbitrary line separating the Tuscarora Sandstone from Clinton/Medina sandstones.

Very fine- to fine-grained sandstone consisting of quartzarenite and locally sublitharenite and subarkose constitutes the reservoir in these plays. Compaction and burial diagenesis have greatly reduced the primary intergranular porosity of the reservoir. Secondary intergranular porosity, caused by the dissolution of rock fragments, feldspar grains, and cement, and fracture porosity, caused by movement between basement-involved fault blocks, are the important porosity types in the plays. Porosity for the reservoirs ranges from 3 to 11 percent and averages 5 percent.

Permeability is as high as 0.6 millidarcy but generally averages less than 0.01 millidarcy. The thickness of the Clinton sandstone sequence and the Medina Group in the plays ranges from 120 to $210 \mathrm{ft}$, and sandstone to shale ratios vary from 0.6 to 1 . The net reservoir thickness ranges from 2 to $90 \mathrm{ft}$ and averages about $25 \mathrm{ft}$.

The source of the gas in the plays is uncertain. The most plausible candidates are (1) shale and argillaceous limestone of the Middle Ordovician Utica Shale, Antes Shale, and Trenton Limestone, and (2) black shale of the Middle and Upper Devonian sequence. Both proposed source rock sequences are relatively thick and adequately rich in organic matter. However, gas generated from these sequences is not particularly accessible to 
the reservoir sandstones. Vertical migration through several thousand feet of lowpermeability strata is required.

Middle Ordovician source rocks are in the gas generation zone. Vitrinite-reflectance data suggest that Middle and Upper Devonian source rocks in western Pennsylvania, eastern Ohio, and northern West Virginia are mainly in the zone of gas generation, whereas those in western New York and eastern Ohio are in the zone of oil generation. Middle and Upper Devonian source rocks under Lake Erie and in southern Ohio probably are immature with respect to oil and gas generation. Peak gas generation occurred between Late Pennsylvanian and Early Triassic time when these source beds were deeply buried under an eastward-thickening wedge of orogenic sediments and thrust sheets.

Gas was first discovered in the plays in the 1880's in western New York and in the late 1890 's in southern Ohio. Drilling depths to the Clinton and Medina sandstones in these regions range from less than 1,000 to about 2,000 ft. By the late 1950's and early 1960's, exploration activity had successfully expanded into eastern Ohio, northwestern Pennsylvania, and western New York, where sandstone reservoirs are of lower quality, drilling depths commonly exceed $4,000 \mathrm{ft}$, and gas is the dominant hydrocarbon type. Successful exploration for gas continues today in sparsely drilled parts of the plays such as southern and east-central New York, northwestern Pennsylvania, and eastern Ohio. In Pennsylvania and Ohio, drilling depths to the Clinton and Medina sandstones exceed 6,000 ft. An offshore gas well drilled in 1958 in Pennsylvania and numerous offshore wells drilled since 1913 in Canada indicate that gas extends under Lake Erie. Most sandstone reservoirs in the plays have tight-formation status.

Field size has little meaning in the plays because older fields tend to merge into continuous-type accumulations with additional drilling. For example, three Medina gas fields discovered in Chautauqua County, western New York, in the 1960's have now merged into the Lakeshore field, which has an ultimate recovery of about 650 billion cubic feet of gas. This group of plays has the potential for a large volume of undiscovered gas in a continuous-type accumulation.

\section{3.--Upper Devonian Sandstone Gas High Potential 6734.--Upper Devonian Sandstone Gas Medium Potential 6735.--Upper Devonian Sandstone Gas Medium-Low Potential \\ 6736.--Upper Devonian Sandstone Gas Low Potential (modified from original narrative written by Robert T. Ryder)}

The unconventional Upper Devonian Sandstone Gas plays $(6733,6734,6735,6736)$ and the conventional Upper Devonian Sandstone Oil/Gas Play (6737) are contiguous plays in the sandstone depositional system of the Upper Devonian Catskill Delta. Most of the sandstone was deposited in littoral-marine, deltaic, offshore shallow-marine, and turbidite settings. The Upper Devonian Sandstone Gas plays are defined as continuoustype because of low-permeability reservoirs, abnormally low formation pressure, coalesced gas fields, gas shows or production in most holes drilled, and general lack of 
control by anticlinal closure. Stratigraphically, the plays involve numerous formal and informal sandstone and siltstone units deposited during multiple regressive events.

Four Upper Devonian Sandstone Gas plays are recognized. The high potential play (6733) is down-dip of the conventional Upper Devonian Sandstone Oil/Gas Play (6737). The low potential play (6736) wraps around the northern part of the proposed continuous-type accumulation. The eastern and northern boundaries of the plays are marked by the erosional limit of the Upper Devonian sandstone sequence. The western boundary of the plays is marked by the approximate limit of oil production in the Upper Devonian sandstone sequence. The western limit of the plays in southern West Virginia is the depositional limit of the Upper Devonian sandstone and siltstone sequence.

Coarse siltstone and very fine- to fine-grained sandstone, classified as sublitharenite, quartzwacke, subarkose, and quartzarenite constitute the reservoirs in these plays. Compaction and burial diagenesis have greatly reduced the primary intergranular porosity of the reservoir. Secondary intergranular porosity, caused by dissolution of detrital grains (feldspar, metamorphic rock fragments), and silica and (or) calcite cement, and fracture porosity, caused by movement between basement-involved fault blocks, are the important porosity types in the plays. Porosity for the reservoirs ranges from 0.5 to 15 percent and averages 5 percent. Permeability is as high as 2 millidarcies, but averages less than 0.01 millidarcy. Porosity and permeability values are higher than average along the crests of anticlines. The net thickness of the sandstone reservoirs ranges from about 10 to $25 \mathrm{ft}$. Commonly, more than one sandstone reservoir is productive in a given well. Drilling depths are between 2,000 and $6,000 \mathrm{ft}$.

The sources of gas in the plays are the Middle Devonian Marcellus Shale that underlies the Upper Devonian sandstone sequence and the Upper Devonian black shales that intertongue with the Upper Devonian sandstone sequence to the west. These source rocks are between 50 and $400 \mathrm{ft}$ thick and have total organic carbon values between 3 and 5 percent. Source rocks in the northern and southern parts of the plays are in the zone of gas generation, whereas those in the central and eastern parts of the plays are overmature with respect to the generation of oil and gas. Peak gas generation occurred between Late Pennsylvanian and Early Triassic time when the source beds were buried under an eastward-thickening wedge of orogenic sediments.

The first 15-20 gas fields in the plays were discovered from 1865 through 1900 in Armstrong, Cambrian, Elk, Indiana, Jefferson, and Westmoreland Counties, Pennsylvania. These early fields, where drilling depths to Upper Devonian sandstone reservoirs range from 1,500 to $3,000 \mathrm{ft}$, are along the eastern perimeter of the prolific Upper Devonian sandstone oil and gas trend (play 6737). For the next 60 years, new fields were discovered in Pennsylvania along this trend at the approximate rate of one field per year. In the 1960's, exploration shifted to deeper parts of the plays (3,000 to $5,000 \mathrm{ft}$ ) where gas is trapped in low-permeability sandstone reservoirs. In the 1970's and 1980's, approximately 70 new low-permeability fields were discovered in Pennsylvania and 2 were discovered in West Virginia. The number of new accumulations in West Virginia is probably under-represented because Upper Devonian 
sandstone gas discoveries were reported as deeper extensions of existing fields. Successful exploration continues today in west-central Pennsylvania and east-central West Virginia where drilling depths range from about 3,000 to 7,000 ft. Most sandstone reservoirs in the plays have tight-formation status.

Field size has little meaning in the plays because older fields tend to merge into continuous-type accumulations with additional drilling. For example, three Upper Devonian sandstone fields discovered in Centre and Clinton Counties, Pennsylvania, in the early 1980's have now merged into a single accumulation having an ultimate recovery of about 250 billion cubic feet of gas. This group of plays has potential for a large volume of undiscovered gas in a continuous-type accumulation.

\section{0.--Devonian Black Shale - Greater Big Sandy \\ 6741.--Devonian Black Shale - Greater Siltstone Content \\ 6742.--Devonian Black Shale - Lower Thermal Maturity \\ 6743.--Devonian Black Shale - Undeveloped NE Ohio and Western Pennsylvania (modified from original narrative written by Robert C. Milici)}

Black gas-producing shale of Devonian and Mississippian age is present in much of the Appalachian Basin, in an area that extends from New York generally southwestward through Pennsylvania, Maryland, Ohio, West Virginia, eastern Kentucky, and into Tennessee. The shale was deposited along the distal margins of the Acadian Catskill Delta. Sediment input was from the northeast. The western boundary of the plays is the outcrop of the Devonian shale along the western margin of the basin. The southern boundary of the plays is in the Appalachian Plateau regions of Tennessee, where the entire black shale sequence thins to $50 \mathrm{ft}$ or less. At the northern end of the Appalachian Basin, Devonian-Mississippian gas shales are exposed in western and central New York. The eastern margin of the plays is within the Appalachian Plateau, where the blackshale-dominated deltaic sequence gives way eastward to coarser grained siltstone and gray shale that contain less organic matter.

The black shales serve both as source and reservoir for the gas. Production depends upon the coincidence of relatively abundant organic matter at suitable thermal maturity and a reservoir enhanced by a naturally occurring fracture system. In the southern part of the area, fracturing within the shale probably is related to subhorizontal decollement. In the fields of northern Ohio and northwestern Pennsylvania near Lake Erie, fractures may be related to deformation caused by glacial loading and differential isostatic rebound. Shale with total organic carbon content of 2 percent or more extends in a broad band northward from eastern Kentucky and adjacent West Virginia into central Ohio. Vitrinite reflectance increases from about 0.5 to 2.0 percent eastward across the Appalachian Basin. In the productive areas in Virginia, Kentucky, and West Virginia, vitrinite reflectance ranges from about 0.6 to 1.5 percent. Peak generation of hydrocarbons probably occurred during maximum burial late in the Pennsylvanian.

The distal Catskill Delta sequence consists of interbedded black shale facies and gray shale and siltstone facies. Devonian black shales include the Marcellus Shale, 
Rhinestreet Shale Member of the West Falls Formation, Pipe Creek Shale Member of the Java Formation, lower and upper parts of the Huron Member of the Ohio Shale, and Cleveland Member of the Ohio Shale. The black Sunbury Shale is the only gas shale of Mississippian age in this sequence. The greatest thickness of black-shale units is in the depocenter in central Pennsylvania, where together the units are about $1,400 \mathrm{ft}$ thick and constitute about 15 percent of the deltaic sequence. In the productive area in southwestern Virginia, black shale beds constitute about 40 percent of the section, although the entire deltaic sequence is only about $400 \mathrm{ft}$ thick.

The Devonian gas shales are best described as regional, continuous accumulations having variable production characteristics. Production depths range from several tens of feet to several hundreds of feet in the fields near Lake Erie to 5,000 feet or more in southwestern Virginia. Productive horizons are separated by less fractured fine-grained siliciclastic units having relatively low organic-carbon content.

The first gas well in the United States was drilled in Fredonia, New York, in 1821, in shale beds overlying the black Dunkirk Shale. Since then, Devonian shales have yielded about 3.0 trillion cubic feet of gas. At present, gas is produced from Devonian and Mississippian black shales in three general regions in the Appalachian basin. A major producing area in southernmost Ohio, eastern Kentucky, southwestern West Virginia, and southwestern Virginia includes the Big Sandy gas field and several nearby smaller fields. This area constitutes the Devonian Black Shale - Greater Big Sandy Play (6740), the most productive shale-gas play in the Appalachian Basin. In this area, the cumulative thickness and organic richness of the black gas shales is relatively great and decollement-related fractures provide the permeability necessary for gas to move to the well bore. More than 10,000 wells produced more than 2.5 trillion cubic feet of gas from the Big Sandy gas field between 1921 and 1985.

A continuation of the Big Sandy producing area extends northward into West Virginia and nearby counties in southeastern Ohio. For purposes of this assessment, this "emerging area" play is characterized by its greater siltstone content (play 6741). The black and gray shale formations, rich in organic matter, are interstratified (diluted) with gray and greenish-gray shales and siltstones, and very fine-grained sandstones, all relatively lean in organic matter. As a result of this overall low content of organic matter, the Devonian Black Shale - Greater Siltstone Content Play (6741) might ultimately prove marginal.

Low-pressure fields in the Devonian Black Shale - Lower Thermal Maturity Play (6742) have been producing gas from fractured Devonian shales near Lake Erie for more than 100 years in an area of relatively low thermal maturity. Glacial loading by ice as thick as $6,500 \mathrm{ft}$ and post-glacial isostatic rebound appear to have created the fractured pathways for gas to migrate from black shale source rocks into intercalated brittle silty and sandy reservoirs. Drilling commenced in Pennsylvania in the 1850's and extended into Ohio a decade later. Hundreds of wells have been drilled, chiefly for domestic production. The wells decline slowly and may produce gas for 50 years or more. 
A dozen or more shale-gas wells in the Devonian Black Shale - Undeveloped NE Ohio and Western Pennsylvania Play (6743) were drilled in western Pennsylvania south of the production near Lake Erie during the late 1970's and early 1980's. Although most of these wells either produced, or have the potential to produce gas from the Devonian shale and siltstone sequence, the play is relatively untested.

The Devonian Black Shale gas plays represent a regional accumulation that has produced moderate quantities of natural gas over many years. Estimated additional recoverable resources are large, and their future production depends primarily on the economics of the natural gas industry and on improved technology for production. Favorable areas are those having relatively high amounts of organic matter, suitable thermal maturation, and natural fracture systems. 